\title{
山形鋼筋違接合部に対して方杖を 付加する耐震補強構法の性能確認 \\ STUDY ON THE SEISMIC RETROFIT OF ANGLE BRACE JOINT USING KNEE MEMBERS
}

\author{
前澤将男*1, 桑田涼平*1, 石田孝徳 ${ }^{* 2}$, \\ 吉敷祥一*3, 薩川恵一 ${ }^{* 4}$, 山田哲*5 \\ Masao MAEZAWA, Ryohei KUWADA, Takanori ISHIDA, \\ Shoichi KISHIKI, Keiichi SATSUKAWA and Satoshi YAMADA
}

\begin{abstract}
Seismic retrofit method with the knee members for preventing the joint fracture of the angle brace was proposed. A series of loading test and analysis have been carried out to investigate validity of this method. The joint fracture prevention was confirmed by installing the knee members. The load sharing ratio could be expressed by the proposed model. Consideration is needed by the load sharing ratio changed by holding angle of the knee members, the installed height of the knee members, stiffness of the knee members and holding angle of a brace to make this method reach the reinforcement target.
\end{abstract}

Keywords : Angle brace joint, Fireless seismic retrofit method, Knee members 山形鋼笳違接合部，無火気而震補強構法，方杖

\section{1.はじめに}

鋼構造の生産施設などの比較的大空間を必要とする建築物では, 張間ラーメン,桁行筋違構造が多用される.筋違構造における筋違は 地震力に対する架構の耐力・勒性を決定する主要素であり,大地震時 に筋違の母材鉄骨の塑性化により地震エネルギーを吸収することを 志向した設計が多い.この設計の前提条件は,筋違の母材鉄骨が十分 に塑性化するまで接合部が破断しないことであり,1981 年施行の新 耐震設計基準により設計された建築物(以下,新耐震建築物と記す)で は筋違接合部の保有耐力接合の検討が法的に義務付けられている.

一方で,新耐震設計基準の施行前に設計された,いわゆる旧耐震設 計の建築物(以下,旧耐震建築物と記す)では筋違接合部の保有耐力接 合の検討がなされていない.1995 年兵庫県南部地震 ${ }^{1}$ および 2011 年 東北地方太平洋沖地震 2)等の被害調査結果では,新耐震建築物の筋違 接合部における保有耐力接合の有効性が証明されると共に,旧耐震 建築物の筋違接合部における破断被害が報告されている.今後, 南海 トラフ地震や首都圈直下型地震といった巨大地震の発生が懸念され る状況下では, 旧耐震建築物の筋違接合部の早期破断防止に向けた 補強部材の新設,既存接合部の補強および既存部材の取替等の耐震
改修の促進が課題である.

実際の耐震改修推進における阻害要因は,施工中の室内空間の使 用制約であり,部材の新設によるスペース制約,施工に伴う安全対策 および施工に伴う振動・騒音である.特に鋼構造建築物の耐震改修工 事では溶接・ガス切断が多用されるため,火花・有毒ガスの発生に対 する火気養生,換気対策および現場溶接の品質確保といった問題が ある.生産施設などのように建築物内の補強スペースが狭险で引火 物が多い場合では, 補強スペースがコンパクトで溶接・ガス切断な ぞの火気が不要(以下,無火気と記す)な構法のニーズが高い.既存鋼 構造建築物の無火気補強構法に関寸る研究として柱,梁, トラスおよ び筋違といった既存部材の耐力向上や補強部材の新設を狙い,摩擦 接合金物,エポキシ系接着剤およびビスなどを用いて補強部材を接 合する研究 3) 6)が行われている.

鋼構造の旧耐震建築物における筋違接合部の補強や耐震性評価に 関する研究 7) 8) は,体育館等の公共建築に多用されている山形鋼筋 違の接合部を対象に精力的に行われ,その成果は広く耐震改修設計 に活用されているが,無火気補強構法を対象とした研究は少ない.

本研究では旧耐震建築物の山形鋼筋違の接合部を対象に無火気で
*1 日本製鉄(株) 修士 (工学)

*2 東京工業大学科学技術創成研究院未来産業技術研究所 助教・博士 (工学)

*3 東京工業大学科学技術創成研究院未来産業技術研究所 准教授・博士 (工学)

*4 愛知工業大学工学部建築学科 教授 · 博士 (工学)

*5 東京工業大学科学技術創成研究院未来産業技術研究所 教授・博士 (工学 $)$
Nippon Steel Corporation, M.Eng.

Assist. Prof., FIRST, IIR, Tokyo Institute of Technology, Dr.Eng.

Assoc. Prof., FIRST, IIR, Tokyo Institute of Technology, Dr.Eng.

Prof., Dept. of Architecture, Aichi Institute of Technology, Dr.Eng. Prof., FIRST, IIR, Tokyo Institute of Technology, Dr.Eng: 
の補強を狙い,筋違の接合部近傍に設置した鋼製方杖(以下,方杖と記 す)を高力ボルトにより接合する構法(以下,本構法と記す)について 提案した. 本構法は筋違の接合部における, 筋違のファスナー孔欠損 部,筋違のはしあき部,ファスナー,ガセットプレートおよびガセット プレート溶接部で不足する荷重伝達量を方杖により付加される新た な荷重伝達経路により補い,筋違の接合部の早期破断を防止するこ とを意図した.そして,本構法の補強部を構成する方杖の取付角度を 実験因子とした載荷実験および解析を行い, 本構法の有効性につい て検討した. なお,本論文は 2017 年日本建築学会大会学術講演 9)で 発表した内容に加筆したものである.

\section{2.本構法の概要}

Table1 に本構法の概要を示す.本構法の対象は, $\mathrm{H}$ 形鋼柱のフラ ンジにガセットプレートを溶接し,その片側に山形鋼筋違がファス ナーで接合された接合部であり,柱・梁接合部は剛接合である.

本構法では,柱・梁および筋違端部の接合部が集中寸る範囲の補強 を回避して施工を簡易化することを狙った。

Fig.1 に本構法の施工手順を示す.まず, Fig.1(a)に示すように筋違, 柱および梁にファスナー孔を設ける.次に, Fig.1(b)に示すように柱 側・梁側の方杖の位置決めをする.なお,鋼板を用いた方杖の中間部 には 2 箇所の高力ボルト接合部を設けて方杖の位置調整を可能とし た.最後に, Fig.1(c)に示すように方杖と筋違, 柱および梁を高力ボル トで接合することで無火気での現場施工を可能とした.

この構成により, Table1 に示すように筋違の引張荷重の一部は, 筋違の突出脚から高力ボルト摩擦接合部, 方杖を介して, 柱および梁 に伝達される.その結果, 方杖を設置する前の筋違接合部の破断耐力 が,筋違のファスナー孔欠損部の破断,ファスナーの破断,筋違のはし あき破断,ガセットプレートの破断およびガセットプレート溶接部 破断のいずれで決まる場合においても,方杖を設置した後は筋違と 方杖からなる部分(以下, 補強部と記す)の耐力は, 方杖を設置する前 の筋違接合部の破断耐力より増加する.従って, 筋違が軸部降伏耐力 (筋違母材の全断面積に降伏応力度を乗じた值)に達する前の補強部 内部にある筋違接合部の破断防止が可能となる.(以下,筋違について, 補強部内部を補強筋違, 補強部外部を既存筋違と記し, 両者を合わせ て筋違と記す).

Fig. 2 に本構法の施工における利点である方杖の取付パターンを 示す.まず,Fig.2(a)は方杖設置に伴う障害物が無く, 柱・梁側の方杖 を同じ取付角度で設置する場合である. 次に,Fig.2(b)は柱・梁側の 方杖と柱・梁の接合部近傍に障害物があり, 柱・梁側の方杖の取付角 度を別々にした場合である.最後に, Fig.2(c)は方杖と筋違の接合部 近傍に障害物があり, 方杖の取付位置 $r$ を上に移動した場合である.

本構法では方杖の取付角度や取付位置の設定により,障害物の回 避できる施工を可能とする.

\section{3. 載荷実験}

\section{1 実験概要}

Fig.3(a) に試験体のモデル化範囲を, Fig.3(b)に試験体のセット アップを示す. 試験体は実在の旧耐震建築物の筋違と柱梁接合部周 辺を実大サイズでモデル化した。筋違の取付角度 $\theta=55^{\circ}$, 補強筋違 の接合部(1)および既存筋違の接合部(2)の第 1 ファスナー孔の中心間
距離 $L_{b}=4,200 \mathrm{~mm}$, 方杖の取付位置 $r=970 \mathrm{~mm}$ であり $, 2,000 \mathrm{kN}$ アク チュエーターを用いて正負交番漸増繰返載荷を行った.

Fig.4(a)に標準試験体(後述する Table3 の No.3 specimen)の全体 図を示す.筋違には L- $75 \times 75 \times 6(\mathrm{SS} 400)$ を用いた.接合部(1)は実在 の非保有耐力接合を再現しており,高力ボルトの径,本数,配置および ガセットプレート形状の組み合わせにより,補強筋違のファスナー 孔欠損部の有効断面破断にて耐力が決定している.なお,既存のガセ ットプレートと柱の接合について,実際は溶接であるが,実験では試 験体の取替を考慮して高力ボルト摩擦接合とし,高力ボルトの寸心゙ り耐力を筋違の基準強度 $F$ に基づく軸部降伏耐力の 1.2 倍より大き くした. 接合部(2)は実在の接合部とは異なり,試験用に保有耐力接

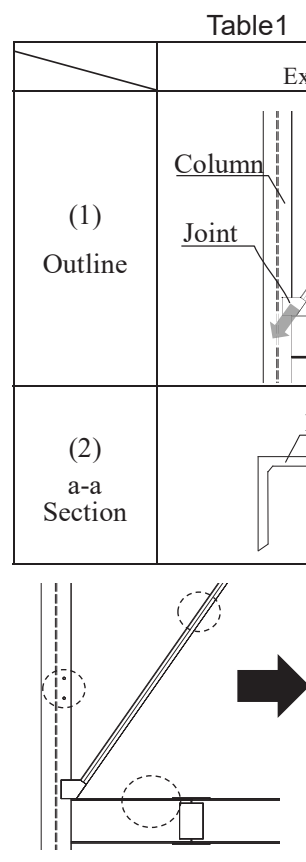

(a)Drilling
Table1 Proposed retrofitting method

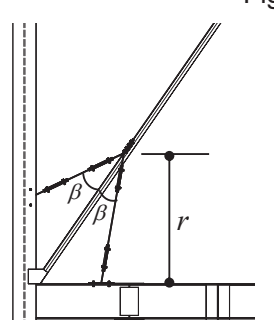

(a)Same angle
Fig.1 Construction procedure

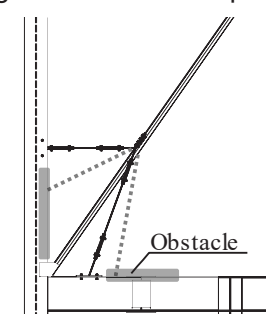

(b) Changing the angle
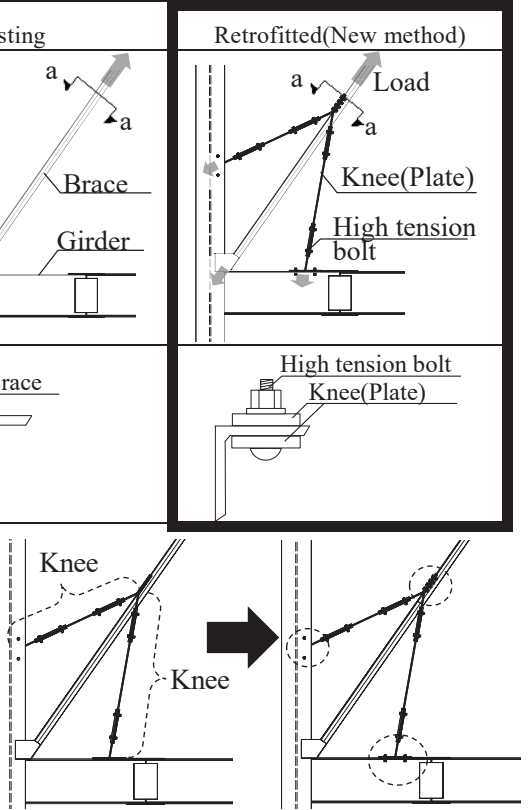

(c)Tightening
(b)Setting knee member

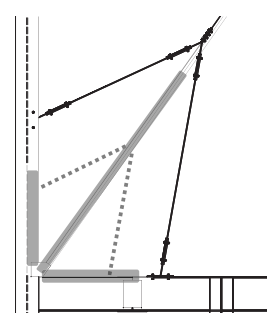

(c)Change of length
Fig.2 Pattern of reinforcement

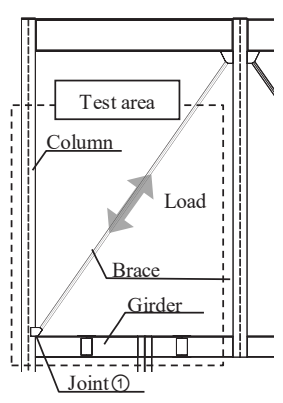

(a)Test zone

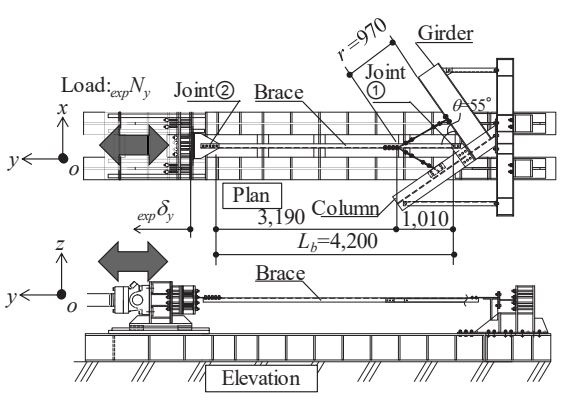

(b)Set up
Fig.3 The outline of a loading test 
合の高力ボルト摩擦接合とし, 耐力決定要因となる既存筋違のファ スナー孔欠損部の破断耐力は筋違の基準強度 $F$ に基づく軸部降伏耐 力の 1.2 倍の值より大きくした.

Fig.4(b)に柱・梁接合部の詳細を示す.梁は実在同様の H-450×200 $\times 9 \times 14(\mathrm{SS} 400)$ とし, 柱との接合部は実在同様に剛接合とした。柱 は試験体設置の都合上,実在(H 形鋼)の $1 / 2$ 断面を CT- $396 \times 300 \times 14$ $\times 22(\mathrm{SS} 400)$ により再現した.なお，Fig.4(a)に示すように実在の 梁・柱に取付く床板, 間柱, 胴縁などによる変形抑制効果を模擬する ため,柱・梁端部之試験治具の H 形鋼 $\mathrm{H}-300 \times 300 \times 10 \times 15(\mathrm{SS} 400)$ の端部に試験治具の山形鋼 L- $75 \times 75 \times 6(\mathrm{SS} 400)$ を架け渡し, 高力ボ ルト 1 本で接合して,ピン接合と仮定した.

Fig.4(c)に柱・梁側の方杖の詳細を示す.方杖は PL-12×60(SS400) を用いて,中間に 2 籄所の高力ボルト摩擦接合部を設けて現場施工 における位置調整を,ボルト孔のクリアランスでできるようにした. 方杖と筋違の接合は高力ボルト摩擦接合として, 接合部(1),(2)の突出 脚側に設け,接合部(1)側の高力ボルト 1 本は方杖と補強筋違の離間 防止用と考え,残る接合部(2)側の高力ボルトのすべり耐力は, 筋違の 基淮強度 $F$ に基づく軸部降伏耐力の 1.2 倍となる前提で算出した方 杖の存在応力 (以下, 設計応力と記す)を上回るように設計した.梁側 方杖と梁フランジの接合部は Fig.4 (c)の【C element】に示すスプ リットティー形式として,スプリットティーの弾性限耐力は, 梁側の 方杖の設計応力を上回るように設計した.柱側方杖と柱フランジと の接合は Fig.4 (c)の【D element】に示寸接合部プレート(PL-9)の 面内曲げによる荷重伝達の形式として, 接合部プレートの弾性限耐 力は,柱側の方杖の設計応力を上回るように設計した.方杖と筋違,柱, 梁との接合は高力ボルト摩擦接合とし, 実施工と同様に筋違, 柱, 梁の 摩擦処理(赤錆処理等)は省略し,すべり係数は鋼構造接合部設計指針 10)の黒皮同士のすべり係数 0.23 を用いた.

Table 2 に試験体の筋違および方杖に用いた鋼材から切り出した JIS5 号試験片の引張試験結果を示す。

Fig.5 に計測計画を示す.荷重 $e_{x p} N_{y}$ はアクチュエーターに取り付け たロードセルによって計測した. 変位計は筋違の材軸変形の計測用 に加力側には $\delta_{1}, \delta_{2}$, 反力側には $\delta_{3}$ の計 3 箇所に設置した.なお,後述の 載荷実験結果の筋違の材軸方向変形 ${ }_{\text {exp }} \delta_{y}$ は $\left(\delta_{1}+\delta_{2}\right) / 2-\delta_{3}$ とした.歪は Fig.4(a)の筋違の【a-a section】および方杖の【b-b section】に示し た $\nabla$ 位置に取付けた一軸ゲージで計測した。

Fig.6 に載荷履歴を示す.載荷は筋違の材軸方向変形 $\exp \delta_{y}$ を前述の $L_{b}$ で除した平均歪 $($ Fig.5 の $y$ 軸正方向が引張側)で制御し,歪 $2.0 \%$ で破断に至らない場合は,破断に至るまで引張側に歪を増加させた.

\section{2 実験パラメーター}

Table3 に試験体リストを示寸.本実験におけるパラメーターは方 杖の取付角度である.各試験体の確認項目は以下の通りである.

No.1 試験体は既存の無補強試験体であり, 筋違の耐力および変形 性能を確認するための試験体とした.No.2〜 5 試験体は柱・梁両側に 方杖を設置し, 補強部を模擬した試験体である。このうち, No. $2 \sim 4$ 試験体は柱・梁側の方杖の取付角度は等しくし, その取付角度を $15^{\circ} \sim 45^{\circ}$ に変化させて, 取付角度による影響を確認するための試 験体である.一方,No.5 試験体は柱・梁側の方杖の取付角度が異なる 場合の影響を確認するための試験体である.

Table3 には試験体の降伏点,引張強さに基づく計算值の筋違の軸
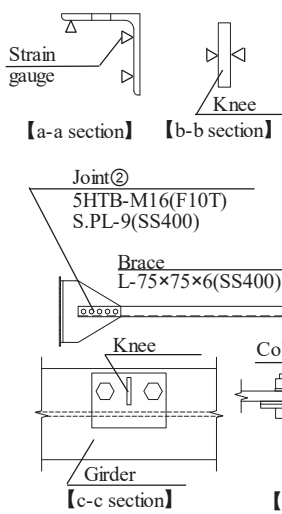

-

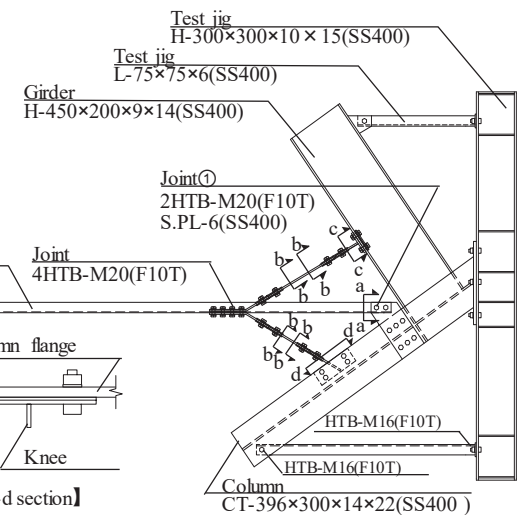

(a) Overall view
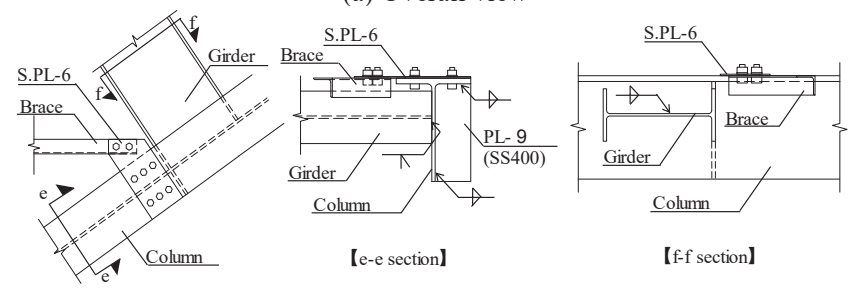

(b) Detail of the existing joint (1)

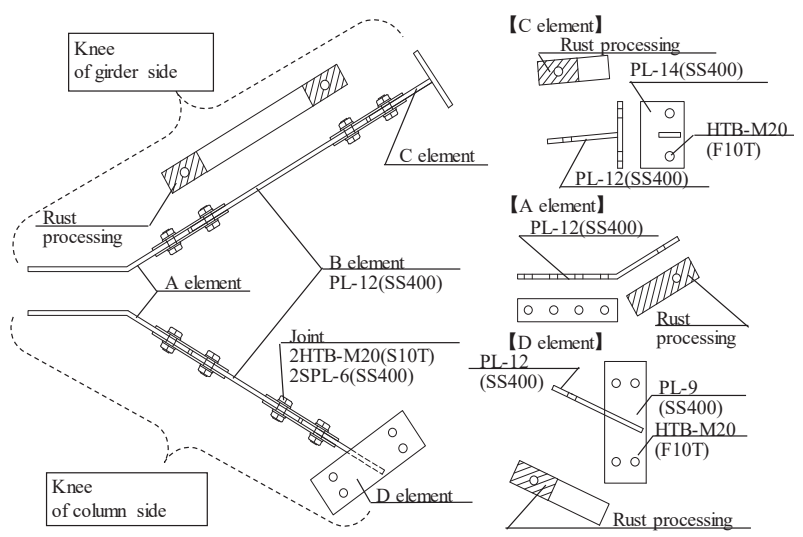

(c) Detail of the knees

Fig.4 Standard specimen(No.3 specimen)

Table2 Mechanical property

\begin{tabular}{|c|l|c|c|c|c|}
\hline \multicolumn{2}{|c|}{ Part } & $\begin{array}{c}\text { Steel } \\
\text { grade }\end{array}$ & $\begin{array}{c}\text { Yield strength } \\
{\left[\mathrm{N} / \mathrm{mm}^{2}\right]}\end{array}$ & $\begin{array}{c}\text { Tensile strength } \\
{\left[\mathrm{N} / \mathrm{mm}^{2}\right]}\end{array}$ & $\begin{array}{c}\text { Elongation } \\
{[\%]}\end{array}$ \\
\hline \multirow{2}{*}{ Brace } & No.2 $\sim 5$ Specimen & SS400 & 319 & 460 & 36 \\
\cline { 2 - 6 } & No.1 Specimen & SS400 & 307 & 445 & 35 \\
\hline Knee & No.2 2 Specimen & SS400 & 307 & 452 & 45 \\
\hline
\end{tabular}

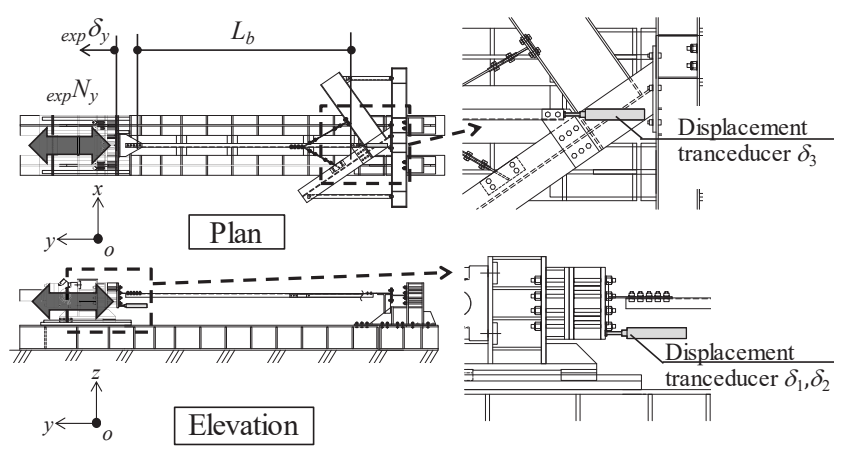

Fig.5 Measurement plan

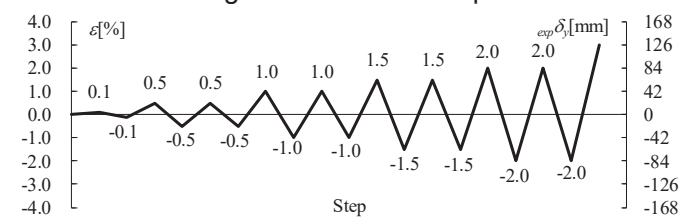

Fig.6 Loading history 
部降伏耐力 $\mathrm{cal} N_{\text {yield }}$, 接合部(1)の破断耐力 ${ }_{\mathrm{cal}} N_{J(1), u}$, 接合部(2)の破断耐力 ${ }_{c a l} N_{J Q 2, u}$ および補強部の耐力の予測值 ${ }_{c a l} N_{R}$ も示した.なお, 各々の耐力 は以下の通り算出した。

接合部の破断耐力の算定において,山形鋼の突出脚の無効長さは 鋼構造接合部設計指針10)を参考に,接合部(1) $0.7 \times 75 \mathrm{~mm}$, 接合部(2) は $0.25 \times 75 \mathrm{~mm}$ とする.ファスナー孔による筋違の断面欠損は(高力 ボルト径 $+2 \mathrm{~mm}$ ) $\times$ 板厚であり,接合部(1)は $22 \times 6 \mathrm{~mm}^{2}$, 接合部(2)は 18 $\times 6 \mathrm{~mm}^{2}$ である.その結果, 突出脚の無効部分とファスナー孔による 断面欠損を除いた筋違の有効断面積は接合部(1) $425 \mathrm{~mm}^{2}$, 接合部 (2)は $650 \mathrm{~mm}^{2}$ となり,No.1 試験体は接合部(1)の筋違のファスナー孔 久損部の破断, No.2〜 5 試験体は接合部(2)の既存筋違のファスナー 孔欠損部の破断で耐力が決まることになる.また,筋違と方杖の接合 部のファスナー孔による筋違の断面欠損は $22 \times 6 \mathrm{~mm}^{2}$ であり, 有効 断面積は $740 \mathrm{~mm}^{2}$ となった.

No.2 5 試験体の補強部の耐力は,簡易的に既存筋違と柱・梁側の 方杖の 3 本の並列バネと仮定し,4.2.2 項で後述する補強筋違母材の 軸方向剛性 $K_{A, M}$, 柱 - 梁側の方杖母材の軸方向剛性 $K_{B, M}, K_{C, M}$ に柱・ 梁側の方杖の取付角度 $\beta_{0}, \gamma_{0}$ の余弦の 2 乗を乗じて筋違の材軸方向に 置換した剛性の比より求めた柱・梁側の方杖の荷重分担量の $y$ 方向 分力を用いて, 接合部(1)が破断する際の, 接合部(1)の破断耐力および 柱・梁側の方杖の荷重分担量の $y$ 方向分力を合算した.その結果,補 強部の耐力は筋違の軸部降伏耐力を上回る予測となっている.

\section{3 実験結果}

Fig.7 に全試験体の荷重一変形関係を示寸. 縌軸は筋違に作用する 軸力 $\exp N_{y}$, 横軸は筋違の材軸方向変形 $\exp \delta_{y}$ である. 図中には, 接合 部(1)の破断耐力の計算值 $c a l N_{J \mathbb{D}, u}$ および接合部(2)の破断耐力の計算 值 ${ }_{\text {cal }} N_{J(2), u}$ を破線で示し, 筋違の軸部降伏耐力の実験值 ${ }_{\text {exp }} N_{\text {yield }}$ を $\nabla$, 接

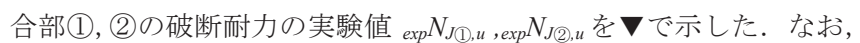
本実験では明確な降伏点が見られなかったため, 筇違の軸部降伏耐 力の実験值は全体の実験データを確認した上で, 降伏棚が現れ始め る時点と概ね対応する, 接線剛性が初期剛性の 1/10 まで低下した時 点での荷重と定義した.また, No.2〜 5 試験体の結果には比較のため にNo.1 試験体の荷重-変形関係を灰色線で示した。

無補強の No.1 試験体は筋違の降伏前の $200 \mathrm{kN}$ 付近で Photo1に 示すように接合部(1)の筋違のファスナー孔より破断に至った. 方杖 を取り付けたNo.2〜 5 試験体は既存筋違の軸部降伏後も耐力を保持 し, 載荷プログラムにおける全サイクルを経て, 単調引張載荷時に 歪硬化に伴い引張耐力が上昇し, 最終的にPhoto 2 に示寸ように接合 部(2)の既存筋違の第一ファスナー孔位置で全断面破断に至った.

筋違両側に方杖を取り付けることで既存筋違の降伏前における, 補強筋違の接合部の破断防止効果を得られることが確認された。

Table3 List of specimen

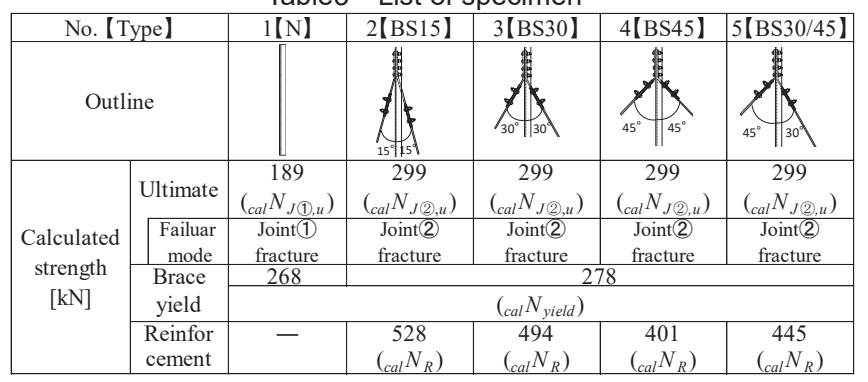

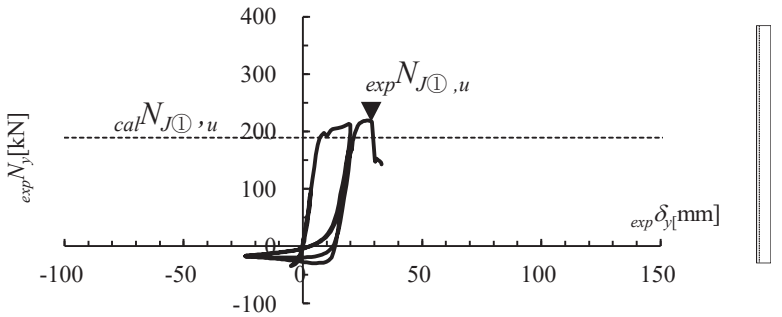

(a) No.1 specimen 【N】

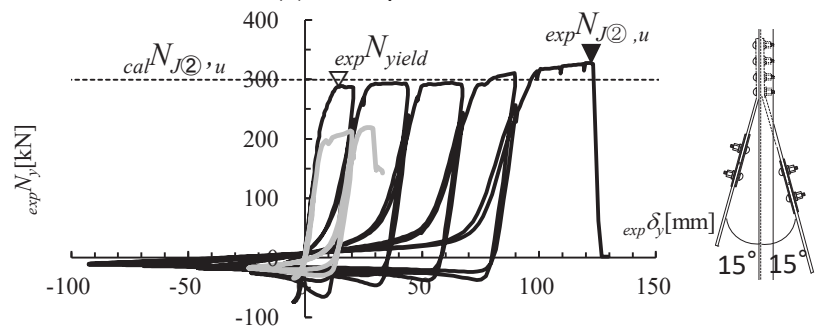

(b) No.2 specimen【BS15】
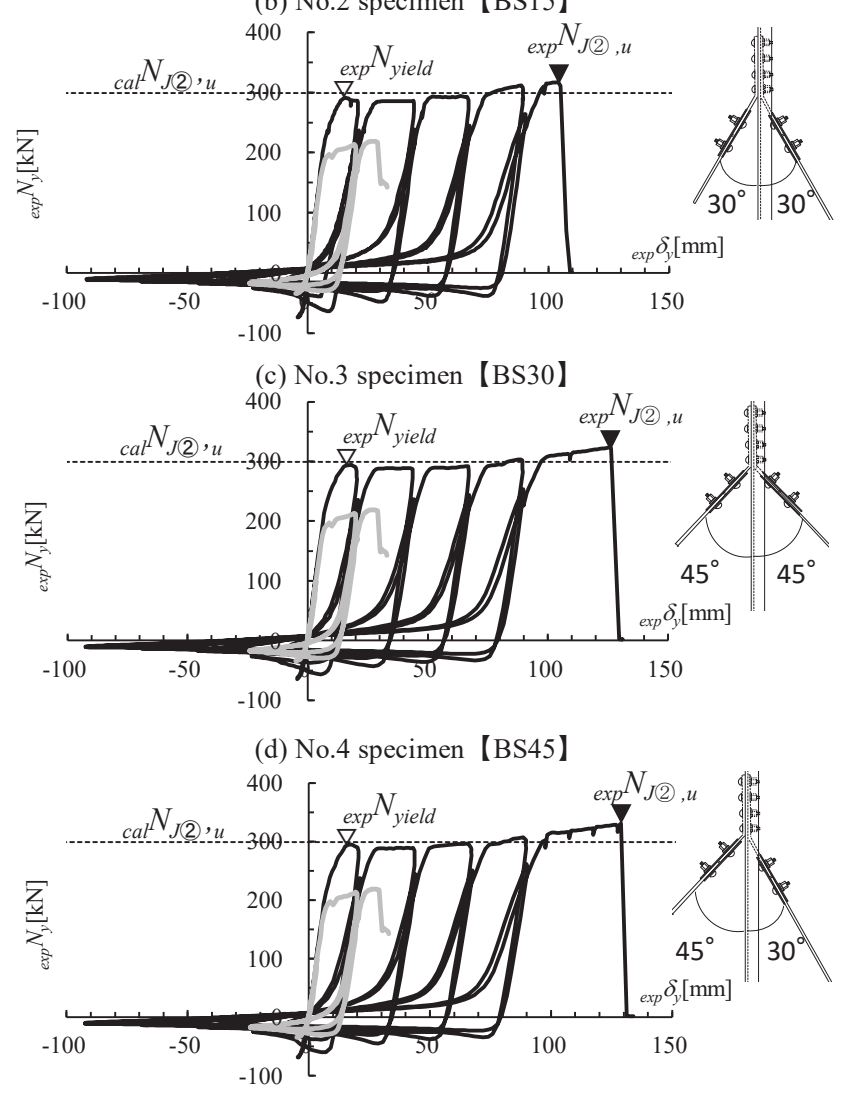

(e) No.5 specimen【BS30/45】

Fig.7 Load - deformation relation

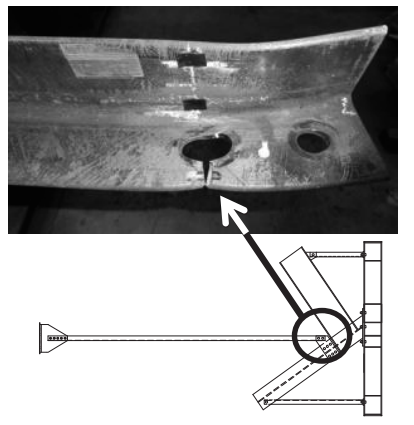

Photo1 Fracture in a joint of no. 1 specimen

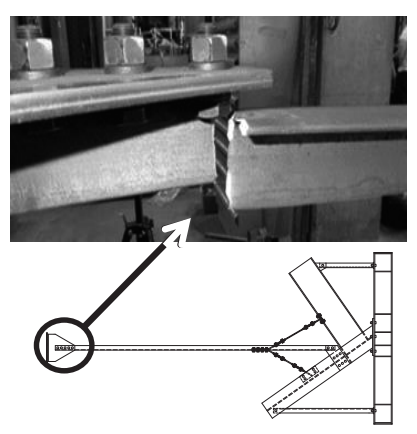

Photo2 Fracture in a joint of no. 2 specimen 
また, 2 本の方杖の取付角度による耐力の有意な差は確認できな かったため, 方杖の取付角度の影響については, 次章で考察する.

\section{4.解析モデルを用いた実験結果の考察}

\section{1 解析モデル}

本章では, 載荷実験における方杖の剛性, 取付角度が耐力に及ぼす 影響について解析モデルを用いて考察する.Fig.8 に試験体の解析モ デル(以下,試験体モデルと記す)を示す.本構法における荷重伝達は 補強筋違,既存筋違および柱・梁側の方杖ともに軸力が支配的になる ため,耐力評価には接合部をピン支点としたトラスモデルを採用し た. Fig.8(b) に示寸補強部における力の釣合は, 補強部の荷重 ${ }^{2} N_{y}$, 補 強筋違の荷重分担量 $c a l N_{A}$, 梁側の方杖の荷重分担量 ${ }_{c a l} N_{B}$ および柱側 の方杖の荷重分担量 $c_{c a l} N_{C}$ の $x, y$ 方向分力を用いて下式で表される.

$$
\begin{aligned}
& { }_{c a l} N_{A, y}+{ }_{c a l} N_{B, y}+{ }_{c a l} N_{C, \mathrm{y}}={ }_{c a l} N_{y} \\
& { }_{\text {cal }} N_{A, x}+{ }_{\text {cal }} N_{C, x}={ }_{\text {cal }} N_{B, x} \\
& \text {. . (2) }
\end{aligned}
$$

${ }_{c a l} N_{y}$ により補強部に変形 ${ }_{\mathrm{c} a l} \delta_{r, x}, \mathrm{cal} \delta_{r, y}$ が生じた場合,各部材の軸方 向変形 $\Delta_{A}, \Delta_{B}, \Delta_{C}$ 下は下式で表される.

$$
\begin{array}{ll}
\Delta_{A}={ }_{c a l} \delta_{r, y} \cos \alpha+{ }_{c a l} \delta_{r, x} \sin \alpha & \cdots \\
\Delta_{B}={ }_{c a l} \delta_{r, y} \cos \beta-{ }_{c a l} \delta_{r, x} \sin \beta & \cdots(3) \\
\Delta_{C}={ }_{c a l} \delta_{r, y} \cos \gamma+{ }_{c a l} \delta_{r, x} \sin \gamma & \cdots
\end{array}
$$

$\alpha, \beta, \gamma$ : 補強筋違および梁・柱側の方杖と $y$ 軸の載荷時の角度 $\beta_{0}, \gamma_{0}$ : 梁・柱側の方杖と $y$ 軸の載荷前の角度(取付角度) ${ }_{c a l} N_{A},{ }_{c a l} N_{B}$ および ${ }_{c a l} N_{C}$ の $x, y$ 方向分力は下式で表される.

$$
\begin{aligned}
& { }_{c a l} N_{A, y}=K_{A} \cos ^{2} \alpha_{c a l} \delta_{r, y}+K_{A} \sin \alpha \cos \alpha_{c a l} \delta_{r, x} \quad \cdots \quad \text { (6) } \\
& { }_{\text {cal }} N_{A, x}=K_{A} \sin \alpha \cos \alpha_{c a l} \delta_{r, y}+K_{A} \sin ^{2} \alpha_{c a l} \delta_{r, x} \quad \cdots(7) \\
& { }_{\text {cal }} N_{B, y}=K_{B} \cos ^{2} \beta_{c a l} \delta_{r, y}-K_{B} \sin \beta \cos \beta_{\text {cal }} \delta_{r, x} \quad \text { ・ . (8) } \\
& { }_{\text {cal }} N_{B, x}=K_{B} \sin \beta \cos \beta_{c a l} \delta_{r, y}-K_{B} \sin ^{2} \beta_{c a l} \delta_{r, x} \quad \text { ・ . (9) } \\
& { }_{\text {cal }} N_{C, y}=K_{C} \cos ^{2} \gamma_{c a l} \delta_{r, y}+K_{C} \sin \gamma_{\cos } \gamma_{c a l} \delta_{r, x} \quad \cdots(10) \\
& { }_{\text {cal }} N_{C, x}=K_{C} \sin \gamma \cos \gamma_{c a l} \delta_{r, y}+K_{C} \sin ^{2} \gamma_{c a l} \delta_{r, x} \quad \cdots(11)
\end{aligned}
$$

$K_{A}, K_{B}, K_{C}$ : 補強筋違および梁・柱側の方杖の材軸方向の剛性

(6),(8),(10)式の第 1 項は $y$ 方向変形 ${ }_{c a l} \delta_{r, y}$ に伴う補強筋違・方杖の 伸びによる補強筋違・方杖の荷重分担量を示している.一方で, 第 2 項は $x$ 方向変形 $c_{a l} \delta_{r, x}$ に伴う補強筋違・方杖の伸縮により付加・削 減される荷重分担量を示している.そして, (6),(8),(10)式より,補強筋 違・方杖の $y$ 方向の荷重分担量は, 各々の部材の剛性,角度および補 強笳違の変形量により決まることを示している.

(6)〜(11)式を(1),(2)式に代入し, ${ }_{, a l} \delta_{r, x, c a l} \delta_{r, y}$ は下式で表される. ${ }_{c a l} \delta_{r, y}={ }_{c a l} N_{y}\left(K_{A} \sin ^{2} \alpha+K_{C} \sin ^{2} \gamma+K_{B} \sin ^{2} \beta\right) /\left\{K_{A} K_{C}(\sin \alpha \cos \gamma-\cos \alpha \sin \gamma)^{2}\right.$ $\left.+K_{A} K_{B}(\sin \alpha \cos \beta+\cos \alpha \sin \beta)^{2}+K_{C} K_{B}(\sin \gamma \cos \beta+\cos \gamma \sin \beta)^{2}\right\}$ • • (12)

${ }_{c a l} \delta_{r, x}={ }_{c a l} N_{y}\left(-K_{A} \sin \alpha \cos \alpha-K_{C} \sin \gamma \cos \gamma+K_{B} \sin \beta \cos \beta\right) /\left\{K_{A} K_{C}(\sin \alpha \cos \gamma\right.$ $-\cos \alpha \sin \gamma)^{2}+K_{A} K_{B}(\sin \alpha \cos \beta+\cos \alpha \sin \beta)^{2}+K_{C} K_{B}(\sin \gamma \cos \beta$ $\left.-\cos \gamma \sin \beta)^{2}\right\}$ ・ $\cdot(13)$

筋違の変形 ${ }_{c a l} \delta_{y}$ は補強部の変形 ${ }_{c a l} \delta_{r, y}$ および既存筋違の変形 ${ }_{c a l} \delta_{e, y}$ 用いて下式で表される.

${ }_{c a l} \delta_{y}={ }_{c a l} \delta_{r, y}+{ }_{c a l} \delta_{e, y}$ $\cdot \cdot(14)$

既存筋違と $y$ 軸の角度 $\omega$ を 0 と仮定し, ${ }_{\text {al }} \delta_{e, y}$ は下式で表される. ${ }_{\text {cal }} \delta_{e, y}={ }_{c a l} N_{y} / K_{D}$ $\cdot \cdot(15)$

$K_{D}$ : 既存筋違の材軸方向の剛性

\section{2 各部材の剛性}

4. 2. 1 剛性のモデル化

Fig.9 に示すように補強筋違および梁・柱側の方杖の材軸方向剛性 は鉄骨母材,接合部および梁・柱の直列バネと仮定し,下式で表した.

$$
\begin{array}{ll}
K_{A}=1 /\left(1 / K_{A, M}+1 / K_{A, J}\right) & \cdots \cdot(16) \\
K_{B}=1 /\left(1 / K_{B, M}+1 / K_{B, J}+1 / K_{B, F}\right) & \cdots \cdot(17) \\
K_{C}=1 /\left(1 / K_{C, M}+1 / K_{C, J}+1 / K_{C, F}\right) & \cdots \cdot(18) \\
K_{D}=1 /\left(1 / K_{D, M}+1 / K_{D, J}\right) & \cdots \cdot(19)
\end{array}
$$

$K_{A, M}, K_{B, M}, K_{C, M}, K_{D, M}$ : 補強筋違,梁・柱側の方杖および既存筋違 における,鉄骨母材の作用軸方向の剛性

$K_{A, J}:$ 接合部(1)の剛性の筋違作用軸方向置換值

$K_{B, J}:$ 梁側方杖・梁の接合部剛性の方杖作用軸方向置換值

$K_{C, J}:$ 柱側方杖・柱の接合部剛性の方杖作用軸方向置換值

$K_{D, J}:$ 接合部(2)の剛性の筋違作用軸方向置換值

$K_{B, F}:$ 梁剛性の方杖作用軸方向置換値

$K_{C, F}:$ 柱剛性の方杖作用軸方向置換値

以下ではそれぞれの剛性の算出について述べる.

\section{2. 2 補強部の鉄骨母材の剛性}

Fig.10 に $K_{A, M}, K_{B, M}$ および $K_{C, M}$ の算出の諸元を示す.なお, $l_{A}$ は補強 筋違における,鉄骨母材の接合部ファスナー孔の中心間距離である。 $l_{B}$ は梁側の方杖における,鉄骨母材の補強筋違近傍の屈曲点から梁 との接合部プレートまでの長さである. $l_{C}$ は柱側の方杖における,鉄 骨母材の補強筋違近傍の屈曲点から柱との接合部プレートまでの長 さである. $K_{A, M}, K_{B, M}$ および $K_{C, M}$ は下式で表した。

$$
\begin{array}{lr}
K_{A, M}=A_{A} E / l_{A} & \cdots \cdot(20) \\
K_{B, M}=A_{B} E / l_{B} & \cdots(21) \\
K_{C, M}=A_{C} E / l_{C} & \cdots \cdot(22) \\
A_{A}, A_{B}, A_{C}: \text { 補強竻違および梁・柱側の方杖の全断面積 } \\
E: \text { 鋼材のヤング係数 }
\end{array}
$$

\section{4,2,3 補強部の接合部の剛性}

Fig.11(a)〜(c)に $K_{A, J}, K_{B, J}$ および $K_{C, J}$ 算出における諸元を示す.モ デル化は以下のよう仮定した.接合部(1)のガセットプレートは片持 梁として,その長さは補強筋違の加力側ファスナー孔と柱の筋違側 ファスナー孔の中心間距離 $l_{A, J}$ とし, 幅は柱の筋違側ファスナー列 の最外縁孔の中心間距離 $B_{A, J}$ とした.梁側方杖の接合部のプレートは

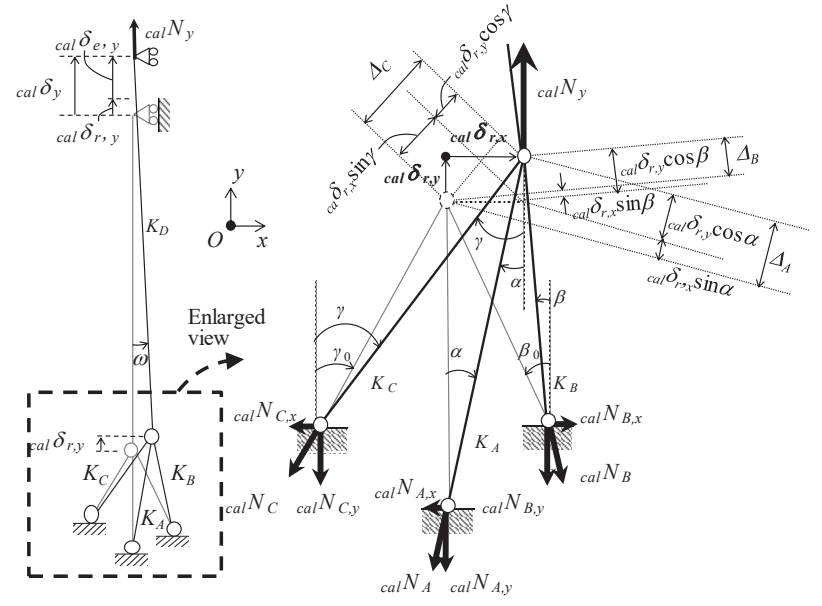

(a) Overall view

(b) Enlarged view of the reinforcing part

Fig.8 The balance of force of experimental model 
両端固定梁として,長さは方杖両側のファスナー孔の中心間距離 $l_{B, J}$ とし,幅は方杖の幅 $B_{B, J}$ と同等とした. 柱側方杖の接合部のプレート は両端固定梁として,長さは方杖両側の柱のファスナー孔の中心間 距離 $l_{C, J}$ とし,幅は方杖片側にある $2 つ$ つァスナー孔の中心間距離 $B_{C, J}$ とした. $K_{A, J}, K_{B, J}$ および $K_{C, J}$ は下式で表した.

$$
\begin{array}{ll}
K_{A, J}=t_{A, J} B_{A, J}^{3} E /\left(4 l_{A, J}^{3} \cos ^{2} \theta\right) & \cdots(23) \\
K_{B, J}=16 t_{B, J}^{3} B_{B, J} E /\left(l_{B, J}^{3} \cos ^{2} \eta\right) & \cdots(24) \\
K_{C, J}=16 t_{C J} B_{C, J}^{3} E /\left(l_{C, j}^{3} \cos ^{2} \phi\right) & \cdots(25)
\end{array}
$$

$\theta, \eta, \phi:$ 筋違および梁・柱側の方杖と梁・柱の取付角度

\section{2. 4 補強部の梁・柱の剛性}

梁・柱については Fig.12 の㨝じり, Fig.13 の曲げ, Fig.14の治具 の軸伸び, 曲げ変形を考慮し, $K_{B, F}$ および $K_{C, F}$ は下式で表した.なお, 本研究では, 梁の長さ $l_{B}$, は柱フェイスからの張出長さ, 柱の長さ $l_{C}$ は 梁フェイスからの張出長さと定義した。

$$
\begin{array}{ll}
K_{B, F}=1 /\left(1 / K_{B, F 1}+1 / K_{B, F 2}+1 / K_{B, F 3}\right) & \cdots \cdot(26) \\
K_{C, F}=1 /\left(1 / K_{C, F 1}+1 / K_{C, F 2}+1 / K_{C, F 3}\right) & \cdots(27)
\end{array}
$$

$K_{B, F 1}, K_{C, F 1}$ : 梁・柱の㨝じり剛性の方杖作用軸方向置換值

$K_{B, F 2}, K_{C, F 2}$ : 梁・柱の曲计剛性の方杖作用軸方向置換值

$K_{B, F 3}, K_{C, F 3}$ : 梁・柱側治具の軸剛性・曲代剛性の 方杖作用軸方向置換值

柱・梁の据じりは方杖と柱・梁の偏心により生じ, $K_{B, F 1}$ および $K_{C, F 1}$ は下式で表した.なお,実験では柱に CT 鋼を用いたので Fig.12 (b)の灰色部分を除いて㨭じり定数および偏心距離 $e_{c}$ を算出した.
$K_{B, F 1}=G J_{B} l_{B} /\left(e^{2} a_{B} b_{B} \cos \eta\right)$
・ $\cdot(28)$
$K_{C, F 1}=G J_{C} l_{C} /\left(e^{2}{ }_{C} a_{C} b_{C} \cos \phi\right)$
$\cdot \cdot(29)$
$J_{B}, J_{C}:$ 梁,柱の据じり定数
$G:$ 鋼材のせん断弾性係数

実験では Fig. 13 に示すように一端固定・他端ピンローラーの梁 の曲げとしたため, $K_{B, F 2}$,および $K_{C, F 2}$ は下式で表した。

$$
K_{B, F 2}=12 E I_{B} l_{B}^{3} /\left\{a_{B}^{2} b_{B}^{3}\left(4 a_{B}+3 b_{B}\right) \cos ^{2} \eta\right)
$$$$
K_{C, F 2}=12 E I_{C} l^{3} d\left\{a_{C}^{2} b_{C}^{3}\left(4 a_{C}+3 b_{C}\right) \cos ^{2} \phi\right)
$$$$
\text { ・ } \cdot(30)
$$$$
\cdot \cdot(31)
$$

$I_{B}$ : 梁の断面 2 次モーメント

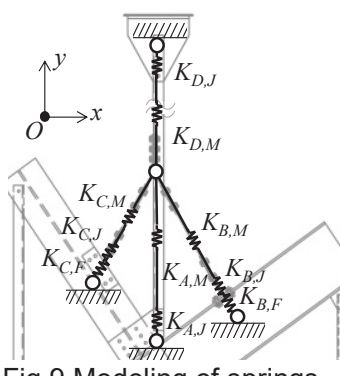

Fig.9 Modeling of springs

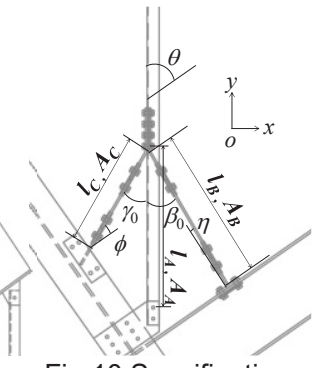

Fig.10 Specifications of reinforcing part

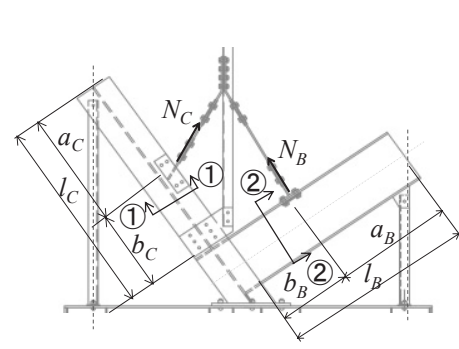

(a)Out line

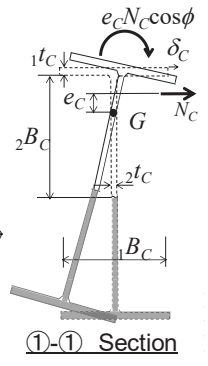

(b) $K_{C, F 1}$
Fig.12 Definition of $K_{F 1}$
$I_{C}:$ 柱の断面 2 次モーメント

治具の剛性評価は実際の架構では不要である.しかし,実験では Fig. 14 に示すように柱・梁の端部反力により治具山形鋼の軸伸び, 治具 $\mathrm{H}$ 形鋼の曲げが生じた. $K_{B, F}$ および $K_{C, F 3}$ は下式で表した. なお, $l_{B 3}, l_{C 3}$ は反力フレームからの治具 $\mathrm{H}$ 形鋼の張出長であり, 剛性を簡易 に算出するため,柱・梁接合部の境界条件はピン接合とした.

$K_{B, F 3}=2 l^{4}{ }_{B} \cos ^{2} \theta /\left\{\cos ^{2} \eta b^{3}{ }_{B}\left(a_{B}+2 l_{B}\right)\left(l_{B 2} / A_{2} E+l_{B 3}^{3} / 3 E I_{3}\right)\right\}$

\begin{tabular}{|c|c|c|c|c|}
\hline angle & $K_{A, M}[\mathrm{kN} / \mathrm{mm}]$ & $K_{B, M}[\mathrm{kN} / \mathrm{mm}]$ & $K_{C, M}[\mathrm{kN} / \mathrm{mm}]$ & $K_{D, M}[\mathrm{kN} / \mathrm{mm}]$ \\
\hline $15^{\circ}$ & & 14 & 185 & \\
\hline$\frac{30^{\circ}}{45^{\circ}}$ & 183 & $\frac{15}{15}$ & $\frac{215}{232}$ & 62 \\
\hline
\end{tabular}

$K_{C, F 3}=2 l^{4}{ }_{C} \sin ^{2} \theta /\left\{\cos ^{2} \phi b^{3}{ }_{C}\left(a_{C}+2 l_{C}\right)\left(l_{C 2} / A_{2} E+l^{3}{ }_{C 3} / 3 E I_{3}\right)\right\}$

\begin{tabular}{|c|c|c|c|c|}
\hline angle & $K_{A, J}[\mathrm{kN} / \mathrm{mm}]$ & $K_{B, J}[\mathrm{kN} / \mathrm{mm}]$ & $K_{C, J}[\mathrm{kN} / \mathrm{mm}]$ & $K_{D, J}[\mathrm{kN} / \mathrm{mm}]$ \\
\hline$\frac{15^{\circ}}{30^{\circ}}$ & & $\frac{474}{419}$ & $\frac{805}{575}$ & \\
\hline $45^{\circ}$ & & $\frac{713}{429}$ & 487 & \\
\hline
\end{tabular}

\begin{tabular}{|c|c|c|c|c|}
\hline & & & & \\
\hline & $K_{A, F 1}[\mathrm{kN} / \mathrm{mm}]$ & $K_{B, F 1}[\mathrm{kN} / \mathrm{mm}]$ & $K_{C, F 1}[\mathrm{kN} / \mathrm{mm}]$ & $K_{D, F 1}[\mathrm{kN} / \mathrm{mm}$ \\
\hline$\frac{10}{30}$ & - & 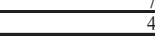 & $\frac{286}{189}$ & - \\
\hline
\end{tabular}

$A_{2}:$ 治具山形鋼の断面積

\begin{tabular}{|c|c|c|c|c|}
\hline & & & & \\
\hline $15^{5}$ & \multirow[b]{2}{*}{-} & $\Lambda_{B, F 2}[\mathrm{KN} / \mathrm{mm}]$ & $\Lambda_{C, F 2}[\mathrm{KN} / \mathrm{mm}]$ & \multirow[t]{2}{*}{ 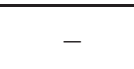 } \\
\hline$\frac{30^{\circ}}{5^{\circ}}$ & & $\frac{2,37}{2,23}$ & $\frac{152}{132}$ & \\
\hline
\end{tabular}

$I_{3}:$ 治具 $\mathrm{H}$ 形鋼の断面 2 次モーメント

\begin{tabular}{|c|c|c|c|c|}
\hline angle & $K_{A, F 3}[\mathrm{kN} / \mathrm{mm}]$ & $K_{B, F 3}[\mathrm{kN} / \mathrm{mm}]$ & $K_{C, F 3}[\mathrm{kN} / \mathrm{mm}]$ & $K_{D, F 3}[\mathrm{kN} / \mathrm{mm}]$ \\
\hline$\frac{15^{\circ}}{30^{\circ}}$ & - & $\begin{array}{r}2,90 \\
63\end{array}$ & $\begin{array}{r}640 \\
212 \\
\end{array}$ & - \\
\hline
\end{tabular}

Table4 Calculation result of stiffness of each part

\begin{tabular}{|c|c|c|c|c|}
\hline angle & $K_{A, F}[\mathrm{kN} / \mathrm{mm}]$ & $K_{B, F}[\mathrm{kN} / \mathrm{mm}]$ & $K_{C F}[\mathrm{kN} / \mathrm{mm}]$ & $K_{D F}[\mathrm{kN} / \mathrm{mm}]$ \\
\hline $\begin{array}{l}\quad 15^{\circ} \\
30^{\circ} \\
4^{\circ}\end{array}$ & - & $\frac{76}{4.3}$ & $\begin{array}{r}115 \\
60 \\
45\end{array}$ & - \\
\hline
\end{tabular}
(a) $K_{M}$

\begin{tabular}{|c|c|c|c|c|}
\hline angle & $K_{,}[\mathrm{kN} / \mathrm{mm}$ & $K_{0}[\mathrm{kN} / \mathrm{mm}$ & $K_{c}[\mathrm{kN} / \mathrm{mm}$ & $K,[\mathrm{kN} / \mathrm{mm}$ \\
\hline$\frac{15^{\circ}}{30^{\circ}}$ & & & & \\
\hline$\frac{30^{\circ}}{45^{\circ}}$ & & 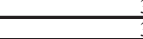 & 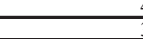 & \\
\hline
\end{tabular}

(b) $K_{J}$

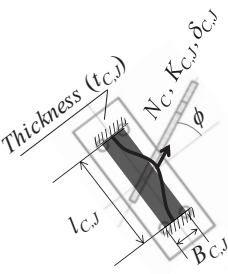

(a) $K_{C, J}$

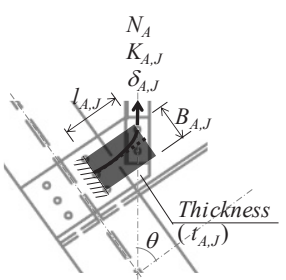

(b) $K_{A, J}$

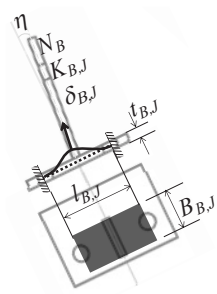

(c) $K_{B, J}$

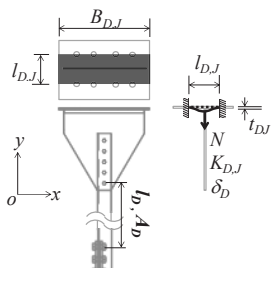

(d) $K_{D, J}$
Fig.11 Definition of $K_{J}$ (c) $K_{B, F 1}$

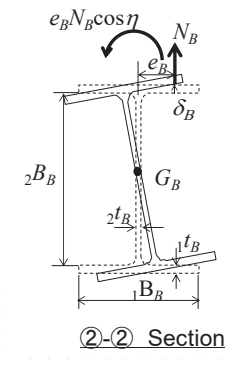

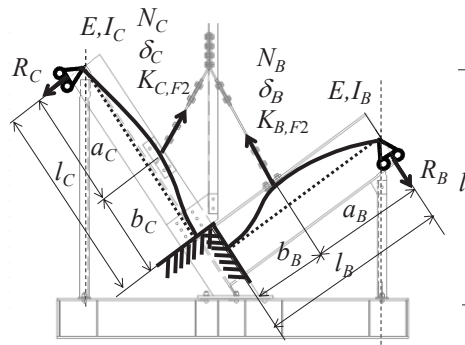

Fig.13 Definition of $K_{F 2}$

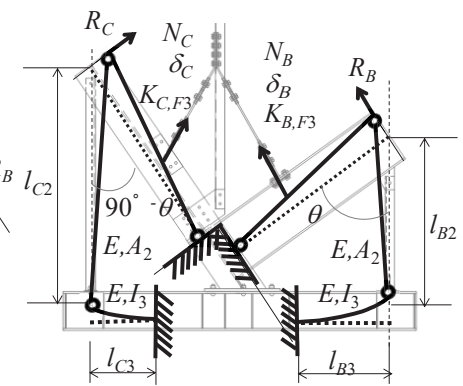

Fig.14 Definition of $K_{F 3}$ 
上記(30)〜(33)式は本研究の載荷実験における柱,梁の剛性であり, 実在の鋼構造建屋では小梁, 床版, 胴縁, 外装材の影響を加味して岡性 を算出する必要がある.

\section{2. 5 既存筋違の剛性}

Fig.11(d)に $K_{D, M}$ および $K_{D, J}$ の算出の諸元を示す.なお, $l_{D}$ は既存筋 違の接合部(2)と方杖取付部のファスナー孔の中心間距離である.ま た, 既存筋違の接合部(2)エンドプレートの曲げが卓越するため両 端固定梁と仮定した. $K_{D, M}$ および $K_{D, J}$ は下式で表した.

$$
\begin{array}{ll}
K_{D, M}=A_{D} E / l_{D} & \cdots(34) \\
K_{D, J}=16 t_{D, J} B_{D, J}^{3} E / l^{3}{ }_{D, J} & \cdots(35)
\end{array}
$$

$A_{D}$ : 既存筋違母材の断面積

Table4 に No.1〜 5 試験体の剛性を算出した結果を示す.

\section{3 実験結果の考察}

本研究では, 筋違の軸部降伏耐力 $N_{\text {yield }}$ に対する補強筋違の荷重分 担量 $N_{A, y}$, 梁側の方杖の荷重分担量 $N_{B}$ の $y$ 方向分力 $N_{B, y}$ および柱側の 方杖の荷重分担量 $N_{C}$ の $y$ 方向分力 $N_{C, y}$ の割合 $N_{A, y} / N_{\text {yield }}, N_{B, y} / N_{\text {yield }}$, $N_{C, y} / N_{\text {yield }}$ を各部材の耐力分担率と定義した.

実験結果の筋違の軸部降伏耐力は Fig7 の $\nabla$ で示した exp $N_{\text {yield }}$ を用 いており, 梁側の方杖の荷重分担量 $\exp _{B} N_{B} お$ よび柱側の方杖の荷重分 担量 exp $N_{C}$ は歪ゲージによる歪計測值より算出し, $y$ 方向分力の exp $_{B, y}$ および ${ }_{\text {exp }} N_{C, y}$ は柱・梁側の方杖の取付角度の余弦を乗じて算出した. そして,補強筋違の荷重分担量 $\exp _{A, y} N_{A \text { exp }} N_{y}$ から $\exp _{B, y} N_{B, y}$ および ${ }_{\text {exp }, y} N_{C, y}$ を減じて算出した.試験体モデルの計算值による筋違の軸部降伏耐 力は前述の ${ }_{\text {cal }} N_{\text {yield }}$ を用いた.

耐力分担率について, 実験結果は $\exp N_{A, y} / \exp N_{\text {yield }}, \exp N_{B, y} / \exp N_{\text {yield }}$, $\exp N_{C, y} /$ exp $N_{\text {yield }}$ であり, 試験体モデルの計算值は ${ }_{\text {cal }} N_{A, y} /$ cal $N_{\text {yield }}$, cal $N_{B, y} /$ cal $N_{\text {yield }}$, cal $N_{C, y} /$ cal $N_{\text {yield }}$ である.

Fig.15 に柱側・梁側の方杖の取付角度が等しいNo.3 試験体, 取付 角度が異なるNo.5 試験体の骨格曲線での耐力分担率-筋違の材軸方 向変形関係の実験結果と試験体モデルの計算值による比較結果を示 す.なお, 試験体モデルの計算値は, まず, (12)・(13)式で補強筋違, 柱 - 梁側の方杖と $y$ 軸の載荷時の角度を各々の部材の取付角度と等 しいとおき $\left(\alpha=0, \beta=\beta_{0}, \gamma=\gamma_{0}\right),{ }_{c a l} N_{y}$ の増分荷重 ${ }_{c a l} \Delta N_{y}$ により生じる補強 部の増分変形 ${ }_{\mathrm{c} a l} \Delta \delta_{r, y},{ }_{\mathrm{c} a l} \Delta \delta_{r, x}$ を求める. 次に,(6) (11)式で補強筋違, 柱・梁側の方杖の増分荷重 $c_{c a l} \Delta N_{A, y}$, cal $\Delta N_{A, x, c a l} \Delta N_{B, y}$, cal $\Delta N_{B, x}$, cal $\Delta N_{C, y}$, cal $\Delta N_{C, x}$ を求める.更に,増分変形により生じた補強筋違,柱・梁側の方杖 の載荷時の角度 $\alpha, \beta, \gamma$ を求める.この荷重増分計算を繰り返した結果 の試験体モデルの計算值を, Fig.15に記号 $(\times, \bigcirc, \triangle, \diamond)$ で示した.

実験結果と試験体モデルの計算值の比較結果より, 両試験体にお いて初期剛性, 而力分担率ともに試験体モデルによる評価で実験結 果を概ね再現できていることが分かる.また, 柱・梁側の方杖の取付 角度の耐力分担率への影響については, No.3 試験体のように取付 角度が等しい場合は梁側方杖と柱側方杖の耐力分担率がほぼ同等に なること, No.5 試験体のように取付角度が異なる場合は耐力分担率 に差が生じることが確認された。

この現象を分析するために,Table5 に,No.3 と No5 の試験体モデル を用いて,前述の $c a l N_{y}$ が増分荷重 $c a l \Delta N_{y}$ による繰り返し計算の結果, ${ }_{c a l} N_{y}={ }_{c a l} N_{\text {yield }}$ に達した際の補強部の変形 ${ }_{c a l} \delta_{r, y}, c a l \delta_{r, x}$ および補強筋違, 柱・梁側の角度 $\alpha, \beta, \gamma$ を初期条件として,(6) (11)式で補強筋違,柱・ 梁側の方杖の荷重分担量および耐力分担率を算出した結果を示す. なお,荷重分担量(6)（11)式の第 1 項,第 2 項の計算結果も示した.

Table5(b),(c)の変形について,No.3,5 試験体ともに $y$ 方向変形 ${ }^{2} a l \delta_{r, y}$ が正側に生じ, $x$ 方向変形 ${ }_{c a l} \delta_{r, x}$ は柱側の方杖の剛性が梁側より高い ため負側に生じる.そして, ${ }_{\text {al }} \delta_{r, y, c a l} \delta_{r, x}$ が極めて小さいため,各部材の 載荷時の角度 $\alpha, \beta, \gamma$ は取付角度とほぼ等しく $\alpha \doteqdot 0, \beta \doteqdot \beta_{0}, \gamma \doteqdot \gamma_{0}$ となる.

Table5(b),(c)の柱・梁側の方杖の荷重分担量については,No.3,5 試験 体ともに以下のようになる. 柱・梁側の方杖の $x$ 方向の荷重分担量 ${ }_{\text {cal }} N_{B, x},{ }_{\text {cal }} N_{C, x}$ はほぼ等しくなる.これは補強筋違の載荷時の角度 $\alpha \fallingdotseq$

\begin{tabular}{|c|c|c|}
\hline & Experiment & Calculation \\
\hline$N_{y} / N_{\text {yield }}$ & - & $\times$ \\
\hline$N_{A, y} / N_{\text {yield }}$ & & $\bigcirc$ \\
\hline$N_{B, y} / N_{\text {yield }}$ & --- & $\Delta$ \\
\hline$N_{C, y} / N_{\text {yield }}$ & $\cdots \ldots \ldots$ & $\diamond$ \\
\hline
\end{tabular}

(a) Legend

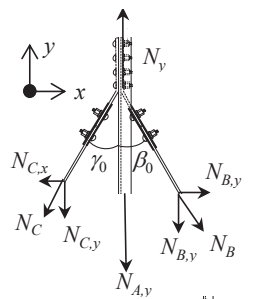

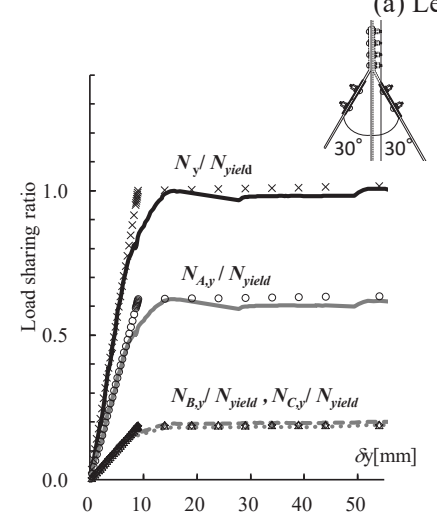

(b) No.3 specimen【BS30】

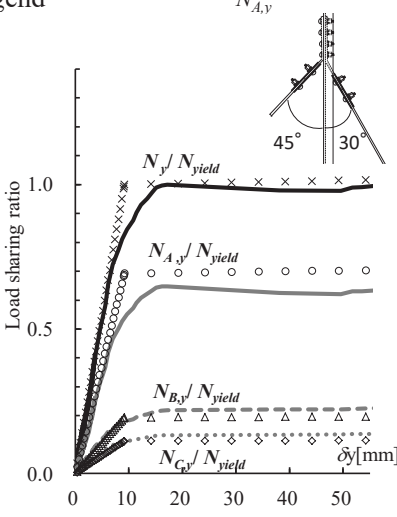

(c) No.5 specimen【BS30/45】

Fig.15 Comparison of the skeleton curve

Table5 Calculation result

(a) Legend

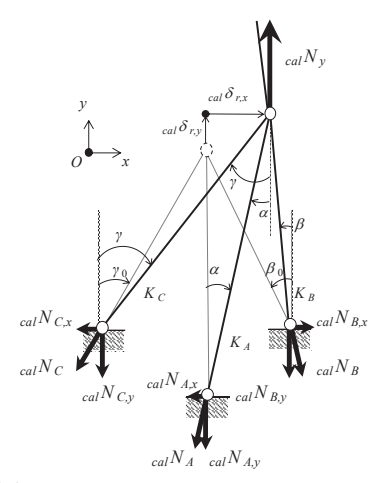

\begin{tabular}{|c|c|c|c|c|c|}
\hline $\begin{array}{c}c^{c a l} N=\text { cal } \\
{[\mathrm{kN}]}\end{array}$ & 278 & $\begin{array}{c}c a l N_{A, y} \\
{[\mathrm{kN}]}\end{array}$ & $192.91+c$ & -0.01 & ) $=192.90$ \\
\hline $\begin{array}{c}K_{A} \\
{[\mathrm{kN} / \mathrm{mm}]}\end{array}$ & 91 & $\begin{array}{c}{ }_{c a l} N_{A, x} \\
{[\mathrm{kNN}]}\end{array}$ & $0.07+($ & 0.00 & )$=0.07$ \\
\hline $\begin{array}{c}K_{B} \\
{[\mathrm{kN} / \mathrm{mm}]}\end{array}$ & 31 & $\begin{array}{c}c a l N_{B, y} \\
{[\mathrm{kN}]}\end{array}$ & $49.53-($ & -4.62 & )$=54.16$ \\
\hline $\begin{array}{c}K_{C} \\
{[\mathrm{kN} / \mathrm{mm}]}\end{array}$ & 35 & $\begin{array}{c}{ }_{c a l} N_{B, x} \\
{[\mathrm{kNN}]}\end{array}$ & $28.55-($ & -2.66 & )$=31.21$ \\
\hline $\begin{array}{c}{ }_{c a l} \delta_{r, y} \\
{[\mathrm{~mm}]}\end{array}$ & 2.16 & $\begin{array}{c}c a l N_{C, y} \\
{[\mathrm{kN}]}\end{array}$ & $37.40+($ & -6.02 & )$=31.38$ \\
\hline $\begin{array}{c}c a l \delta_{r, x} \\
{[\mathrm{~mm}]}\end{array}$ & -0.35 & $\begin{array}{c}c^{c a l} N_{C, x} \\
{[\mathrm{kN}]}\end{array}$ & $37.20+c$ & -5.99 & )$=31.21$ \\
\hline $\begin{array}{c}\alpha \\
{[\text { degree] }}\end{array}$ & 0.02 & \multicolumn{2}{|c|}{${ }_{c a l} N_{A, y} / c a l N_{\text {yield }}$} & & 69.3 \\
\hline $\begin{array}{c}\beta \\
{[\text { degree] }}\end{array}$ & 29.95 & \multicolumn{2}{|c|}{$\begin{array}{c}\operatorname{cal}_{B, y} N_{B, c a l} N_{\text {vield }} \\
{[\%]}\end{array}$} & & 19.5 \\
\hline $\begin{array}{c}\gamma \\
\text { [degree] }\end{array}$ & 44.85 & \multicolumn{2}{|c|}{$\begin{array}{c}c_{c a l} N_{C, y} / c a l \\
{[\%]}\end{array}$} & & 11.3 \\
\hline
\end{tabular}

(b) No.3 specimen

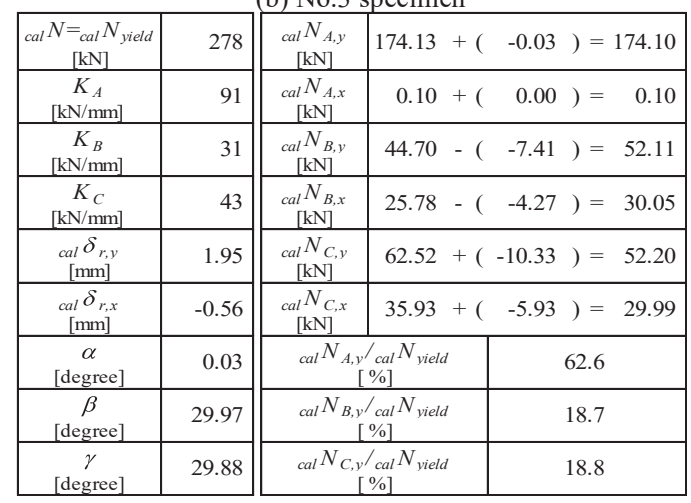

(c) No.5 specimen 
0 のため, $x$ 方向分力 ${ }_{\text {cal }} N_{A, x}$ が極めて小さいためである.一方,柱・梁側 の方杖の $y$ 方向の荷重分担量 ${ }_{c a l} N_{B, y}, c a l N_{C, y} の_{c a l} \delta_{r, y}$ に伴う量((8),(10) 式の第 1 項)は正值となり ${ }_{c a l} \delta_{r, x}$ に伴う量((8),(10)式の第 2 項)は,柱側 の方杖は縮むため負值となり, 梁側の方杖は伸びるため正值となる. そして,第 1 項と第 2 項の合計值 ${ }_{c a l} N_{B, y}, c a l N_{C, y}$ は, ${ }_{c a l} N_{B, x}, c a l N_{C, x}$ を方杖 の載荷時の角度 $\beta, \gamma$ 正接で除した值と等しくなる.そのため, 上述の 通り柱・梁側の方杖の載荷時の角度は取付角度とほぼ等し< $\beta \fallingdotseq \beta_{0}, \gamma$ $\fallingdotseq \gamma_{0}$ となることより,取付角度 $\beta_{0}, \gamma_{0}$ が等しい場合は ${ }_{c a l} N_{B, y}, c a l=N_{C, y}$ はほ ぼ等しくなり, 取付角度 $\beta_{0}, \gamma_{0}$ が異なる場合は ${ }_{c a l} N_{B, y}, c a l N_{C, y}$ に差が生じ ることになる

Fig.16にNo.2〜 5 試験体の耐力分担率の実験結果と試験体モデル の計算值の比較結果を示す. 補強筋違の耐力分担率の誤差 (試験体モ デルの計算值/実験結果) は-10〜+7\% である.この結果より, 提案 した試験体モデルによる耐力評価は概衩妥当であると言える.

\section{5 .解析モデルを用いた検討}

\section{1 検討の方針}

本研究では, 4.2 節で述べた補強筋違の材軸方向の剛性 $K_{A}$ に対寸 る柱・梁側方杖の材軸方向の剛性の $y$ 方向成分の合算值の割合 $\left(K_{B} \cos ^{2} \beta_{0}+K_{C} \cos ^{2} \gamma_{0}\right) / K_{A}$ を補強剛性比と定義した.そして,補強剛性比 と補強筋違の耐力分担率および柱 ・ 梁側の方杖の耐力分担率の合算 值 (以下, 方杖の耐力分担率と記す)の関係について検討した。なお， 以下では既存筇違の軸部降伏耐力 $N_{\text {Fyield }}$ は鋼材の基準強度 $F$ に基づ き算出した值を用いた。

\section{2 試験体モデルを用いた耐力分担率の確認}

Fig.17 に試験体モデルを用いた検討結果を示す. 縦軸は補強筋違 の耐力分担率および方杖の耐力分担率であり, 横軸は補強剛性比で ある.検討は,柱・梁側の方杖の取付角度が同一の場合と異なる場合 について行い,結果を白抜の記号 $(○, \square, \triangle$ 等 $)$ で示したここの結果よ り, 柱・梁側の方杖の軸剛性や取付角度が異なる場合でも,方杖の耐 力分担率は補強剛性比により決定されることが分かる.なお,黒, 灰色

の記号 $(\bullet, \diamond, \ominus, \diamond)$ にて示した結果は 5.3 節で後述する.

\section{3 実在モデルを用いた層間変形角の耐力分担率への影響確認}

地震時における架構の変形を考慮した解析モデル(以下, 実在モデ ルと記す)を用いて, 層間変形角が方杖の耐力分担率に及ぼす影響を 検討した. Fig.18 にモデル図,Table6 に解析条件を示す.

Fig.18(a)に示すように実在モデルの筋違は載荷実験と同じ取付 角度 $\theta=55^{\circ}$ とし, 柱·梁側の方杖の取付位置も載荷実験と同じ位置 $r=970 \mathrm{~mm}$ とした.また,高さ $H=5,600 \mathrm{~mm}$, 幅 $L=3,950 \mathrm{~mm}$ とした. 実在モデルでは, 筋違, 方杖には Table6 に示す軸剛性となるように 断面積を設定し,柱・梁は,両端ピンの剛体とした.Fig.18(b)の灰色線 で示したのは柱 $\mathrm{H}-792 \times 300 \times 14 \times 22$, 梁 $\mathrm{H}-300 \times 300 \times 10 \times 15$, 柱・梁は剛接合の弾塑性解析モデルで既存筋違が層間変形角 $1 / 408$ で軸部降伏した時点での補強筋違周辺の変形図(変形倍率 100)であ り, 実際の架構に層間変形角が生じた場合の柱・梁の曲げ・せん断変 形を模擬している.一方,Fig.18(b)の黒点線で示したのは実在モデル の層間変形角 $1 / 408$ における補強筋違周辺の変形図(変形倍率 100) であり, 実際の架構より, 実在モデルの柱・梁は筋違に近づくことを 示している.なお, Fig.18(b)に示すように柱・梁の両端部とピン支点 の間に極めて短いバネを設けて Fig.18(a)の点線で示すように実在
モデルが平行四辺形に変形できるようにして, 左上柱頭部に強制変 位を与えて層間変形角 1/100 まで変位増分解析を行った。

この実在モデルを用いることで方杖の軸方向の伸び量,荷重分担 量は実際の架構より小さく評価される。検討では,この簡易な実在 モデル用いた略算により,方杖の耐力分担率を安全側に評価した。
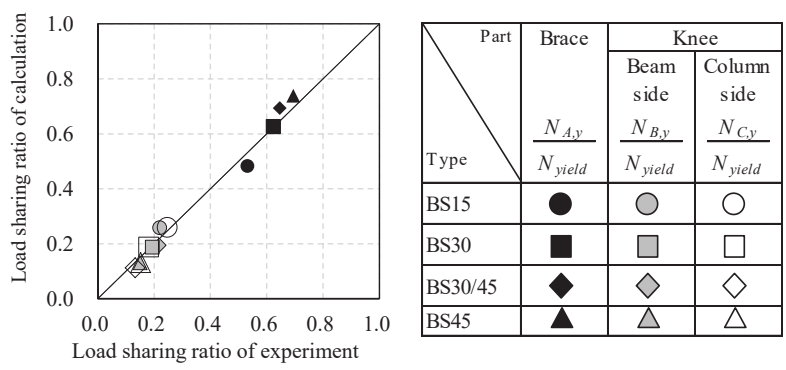

Fig.16 Comparison of load sharing ratio in the case of $N=N_{\text {yield }}$

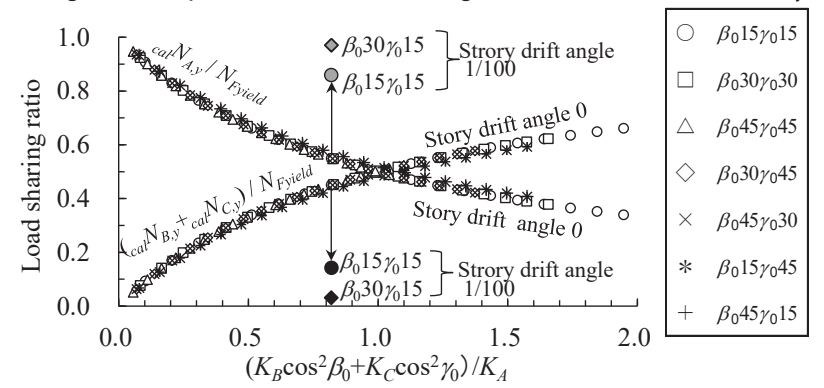

Fig.17 Analysis result of load sharing ratio in the case of $N=N_{\text {Fyield }}$

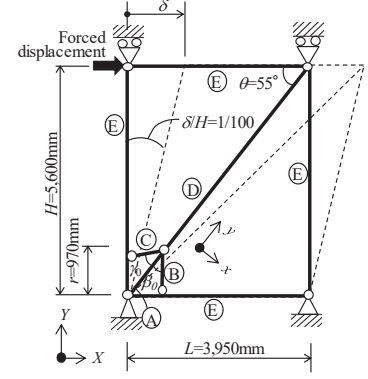

(a) Out Line

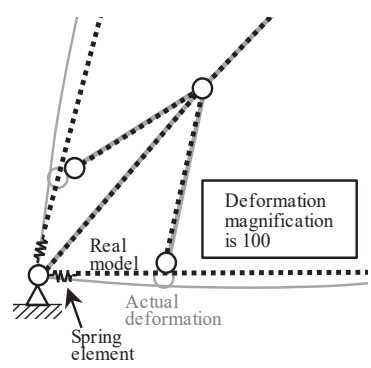

(b) Modeling of column and Girder Fig.18 Analysis model(Real model)

Table6 Analysis conditions

(a) Condition of each part

\begin{tabular}{|c|c|c|c|c|}
\hline & Member & Analysis element & $K$ :Axial stiffness $[\mathrm{kN} / \mathrm{mm}]$ & Material property \\
\hline A & L-75x75x6 & Truss & $K_{A}=91$ & Elastic \\
\hline B & PL & Truss & Parameter & Elastic \\
\hline C & PL & Truss & Parameter & Elastic \\
\hline D & L-75x75x6 & Truss & $K_{D}=32$ & Elastic-Plastic \\
\hline E & Rigid body & - & Rigid & - \\
\hline
\end{tabular}

(b) Parameter

\begin{tabular}{|c|c|c|c|c|c|}
\hline \multirow{2}{*}{ Case } & $\beta_{0}$ & $\gamma_{0}$ & \multicolumn{2}{|c|}{$K$ :Axial stiffness $[\mathrm{kN} / \mathrm{mm}]$} & \\
\cline { 4 - 5 } & {$[\mathrm{deg}]$} & {$[\mathrm{deg}]$} & $K_{B}$ & $K_{C} \cos ^{2} \beta_{0}+K_{C} \cos ^{2} \gamma_{0}$ \\
\hline Same angle & 15 & 15 & 40 & 40 & $K_{A}$ \\
\hline Different angle & 30 & 15 & 50 & 40 & 0.82 \\
\hline
\end{tabular}

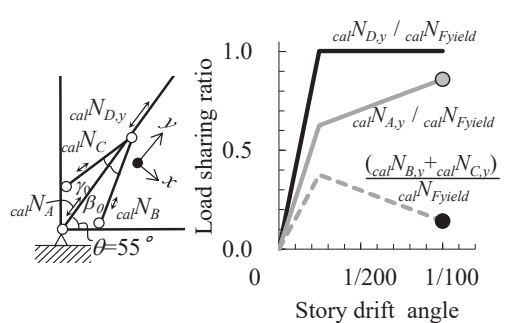

(a) Legend

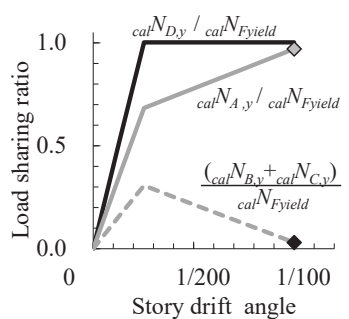

(c) $\beta_{0}=30^{\circ}, \gamma_{0}=15^{\circ}$

Fig19 Analysis result 
Table6 に示すように各部材の復元力は, 既存筋違は軸部降伏耐力 $N_{\text {Fyield }}$ に達すると二次剛性が初期剛性の $1 / 100$ に低下寸る弾塑性とし た.補強筋違, 柱・梁側の方杖は弾性として, 補強部が弾性範囲の耐力 分担率を検討した.パラメーターは柱・梁側の方杖の取付角度および 剛性であり,両側の取付角度が同一のケース $\left(\beta_{0}=\gamma_{0}=15^{\circ}\right.$, 以下, 同一ケ 一スと記す $)$ および異なるケース $\left(\beta_{0}=30^{\circ}, \gamma_{0}=15^{\circ}\right.$, 以下異なるケー スと記す)としたが,両ケースとも補強剛性比は 0.82 とした.

Fig.19に解析結果を示す.縦軸は耐力分担率であり,横軸は層間変 形角である.図中には,補強筋違の耐力分担率を灰色実線で,方杖の耐 力分担率を灰色破線で, 既存筋違の耐力分担率を黒実線で示した. 同一ケース, 異なるケース共に既存筋違の降伏後に方杖の耐力分担 率は低下した. 異なるケースは同一ケースよりも方杖の耐力分担率 の低下が著しく, 補強剛性比よりも方杖の取付角度の影響が大きい ことが分かる.実在モデルの両ケースの層間変形角 1/100 時点におけ る補強筋違・方杖の耐力分担率を Fig.17 に黒・灰色の記号

け)にて示しており,地震時における架構の層間変形角により方杖の 耐力分担率が試験体モデルより低下寸ることが分かる.

この結果より,方杖の耐力分担率は補強剛性比に加えて, 筋違の取 付角度 $\theta$, 方杖の取付位置 $r$, 方杖の取付角度 $\beta_{0}, \gamma_{0}$ の影響を受け, 補強に 必要な耐力分担率を得られる範囲が存在することを示唆している.

\section{4 実在モデルを用いた適用範囲の検討}

本構法の適用範囲を検討するための前提として, 補強筋違の接合 部の破断耐力 $N_{J, u}$ は下式を満足できているものとした.

$0.8 \times 1.1 N_{\text {Fyield }} \leqq N_{J, u}$ ・ ・ (36)

この前提において, 耐震診断および耐震改修指針 ${ }^{11)}$ を参考に, 方 杖の耐力分担率 $\left(\left(N_{B, y}+N_{C, y}\right) / N_{\text {Fyield }}\right)$ の目標值を補強筇違の接合部が筋 違の軸部降伏耐力 $N_{F y \text { yild }}$ に達する前に破断することを防止し, 筋違の 勒性指標 $F_{i}$ が 2.0 以上になるように下式で設定した.

$$
1-N_{J, u} / 1.1 N_{\text {Fyield }} \leqq 0.2 \leqq\left(N_{B, y}+N_{C, y}\right) / N_{\text {Fyield }} \quad \cdots(37)
$$

解析モデルは Fig.18 と同等とし, 検討のパラメーターを Table7 に示す. モデルの高さ $H=5,600 \mathrm{~mm}$ は一定として,筋違の取付角度 $\theta$ は現実的に存在する範囲として $30^{\circ} \sim 60^{\circ}$ とした.方杖の取付位置 $r$ は 施工性を考慮して $500 \sim 1,500 \mathrm{~mm}$ とした.取付角度 $\beta_{0}, \gamma_{0}$ は $15^{\circ} \sim 45^{\circ}$ とし, 補強剛性比は $0.25 \sim 4.0$ とした.方杖の耐力分担率は Fig. 19 と同 様に層間変形角 $1 / 100$ での值を採用した.

Fig. 20 に解析結果 を示す.縦軸は方杖の 耐力分担率を示し,横 軸は補強剛性比を示寸.

Table7 Parameter
\begin{tabular}{|c|l|}
\hline$H[\mathrm{~mm}]$ & $5,600($ constant $)$ \\
\hline$\theta[\mathrm{deg}]$ & $30 \cdot 35 \cdot 45 \cdot 60$ \\
\hline$r[\mathrm{~mm}]$ & $500 \cdot 1,000 \cdot 1,500$ \\
\hline$\beta_{0}=\gamma_{0}[\mathrm{deg}]$ & $15 \cdot 20 \cdot 25 \cdot 30 \cdot 45$ \\
\hline$K_{B} \cos ^{2} \beta_{0}+K_{C} \cos ^{2} \gamma_{0}$ & $0.25 \sim 4.0$ \\
\hline$K_{A}$ & \\
\hline
\end{tabular}

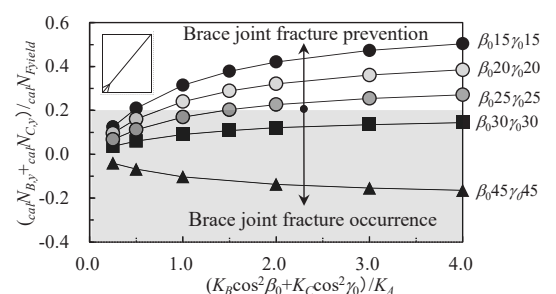

(a) $\theta=60^{\circ}, r=500 \mathrm{~mm}$

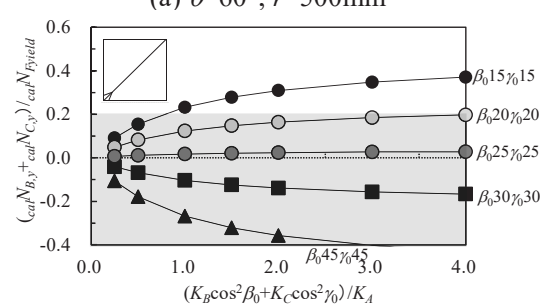

(d) $\theta=45^{\circ}, r=500 \mathrm{~mm}$

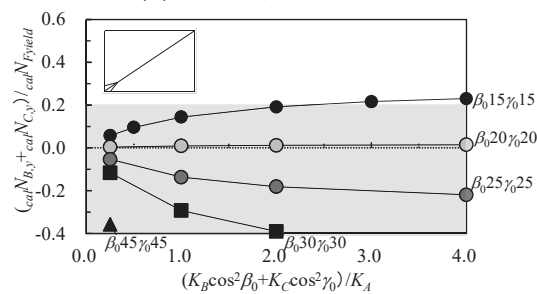

(g) $\theta=35^{\circ}, r=500 \mathrm{~mm}$

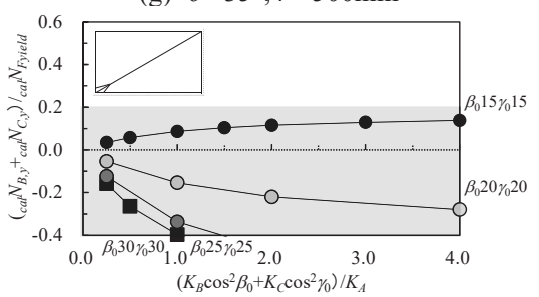

(j) $\theta=30^{\circ}, r=500 \mathrm{~mm}$

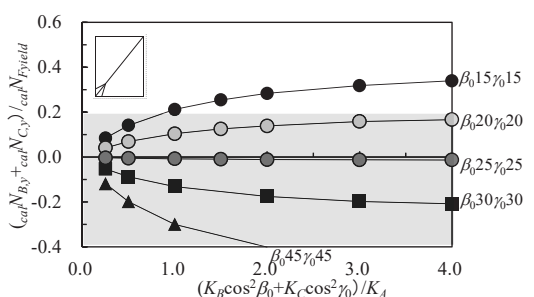

(b) $\theta=60^{\circ}, r=1,000 \mathrm{~mm}$

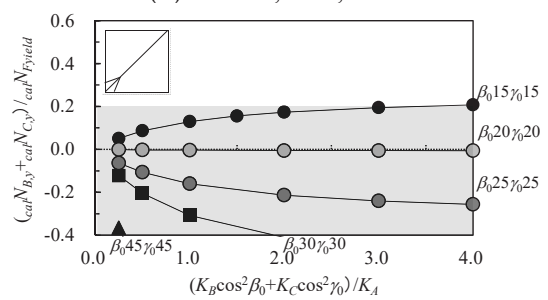

(e) $\theta=45^{\circ}, r=1,000 \mathrm{~mm}$

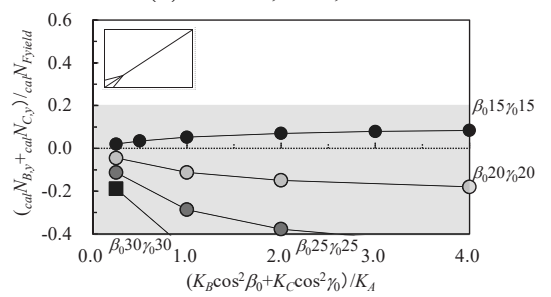

(h) $\theta=35^{\circ}, r=1,000 \mathrm{~mm}$

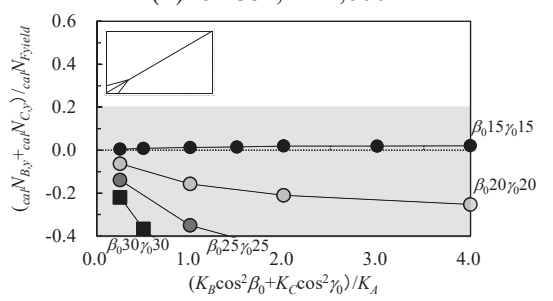

(k) $\theta=30^{\circ}, r=1,000 \mathrm{~mm}$

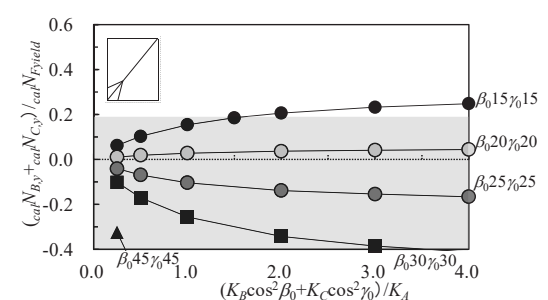

(c) $\theta=60^{\circ}, r=1,500 \mathrm{~mm}$

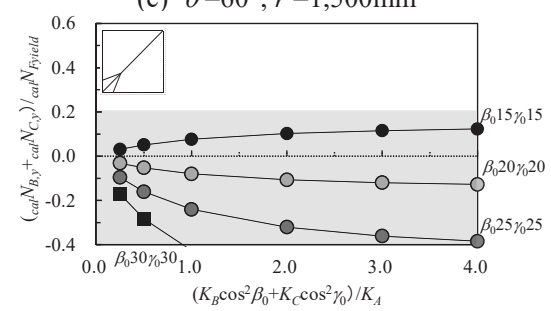

(f) $\theta=45^{\circ}, r=1,500 \mathrm{~mm}$

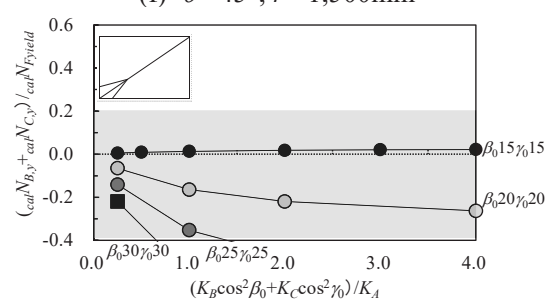

(i) $\theta=35^{\circ}, r=1,500 \mathrm{~mm}$

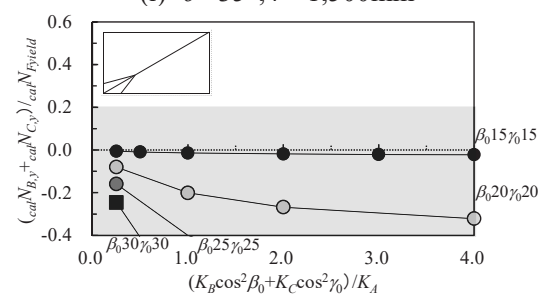

(1) $\theta=30^{\circ}, r=1,500 \mathrm{~mm}$

Fig.20 Load sharing ratio of knee member 
なお,方杖の耐力分担率が負の場合は方杖が圧縮応力になっている ことを示している.図中, 白色部分は耐力分担率が目標値に達して いる範囲を示しており, 灰色部分は耐力分担率が目標值に達してな い範囲を示している.この結果より,筋違の取付角度 $\theta$ 大゙大きなる ほど,また,方杖の取付位置 $r$ が低くなるほど方杖の耐力分担率が高 く, 補強効果が大きくなることを示している.そして, 方杖の設置によ り目標を達成できるのは筋違の取付角度が $35^{\circ}$ 以上,方杖の取付位 置が $1,500 \mathrm{~mm}$ 以下で方杖の取付角度が $25^{\circ}$ 以下のケースに存在し ており,方杖と柱・梁との接合位置を柱・梁接合部に近づけることで, 地震時の層間変形角の影響を受けながらも比較的大きな補強効果を 得られることを示している.なお,柱・梁側の方杖の取付角度が異な る場合については,個別に検討が必要である.

\section{6. まとめ}

本研究では旧耐震建築物の筋違の接合部を対象に, 無火気補強構 法および而力評価のための解析モデルを提案した. 提案した構法の 目的は,接合部で不足する荷重伝達量を方杖により付加される新た な荷重伝達経路により補い,筋違の接合部が筋違の降伏前に破断す ることを防止するためである.この構法の有効性, 解析モデルの妥当 性および適用範囲を検討するために, 方杖の取付角度を試験因子と した載荷実験および方杖の取付位置, 取付角度, 補強剛性比ならびに 筋違の取付角度を解析因子とした解析を行った。

以下に得られた知見をまとめて記す。

[1]載荷実験の結果,筋違の両側の柱・梁側に方杖を取り付けること で,地震時における柱・梁架構の層間変形を考慮しない条件下に おいて,筋違の降伏前の接合部の破断防止効果が得られた.

[2] 載荷実験および解析の結果, 提案する解析モデルにより, 地震 時における柱・梁架構の層間変形を考慮しない条件下において, 筋違が弾性の範囲内の耐力分担率を概㸚再現できた.

[3] 解析の結果, 地震時における柱・梁架構の層間変形を考慮した 条件下において,柱・梁側の方杖の耐力分担率を目標值に到達さ せるには,柱・梁側の方杖の取付角度,位置,補強岡性比および筋 違の設置角度に適用範囲(限界)が存在することを確認した。

\section{謝 辞}

本研究は元東京工業大学院生/西㠃禎希さんにご協力を賜りましたここ こに厚く御礼申し上げます。

\section{参考文献}

1) Editorial Committee for the Report on the Hanshin-Awaji Earthquake Disaster : Report on the Hanshin-Awaji Earthquake Disaster, Maruzen, 2000(in Japanese)

阪神・淡路大震災調查報告編集委員会：阪神 - 淡路大震災調査報告, 丸 善, 2000

2)Yamada, S. , Matsumoto, Y. , Iyama, J. , Ikago, K. , Kishiki, S. , Ikenaga, M. , Shimada, Y. , Koyama, T. , Minami, S. and Asada, H. : Reconnaissance of Damaged Steel School Buildings due to the 2011 Tohoku Earthquake Outline of the Reconnaissance, AIJ Journal of Technology and Design, Vol18, No40, pp. 935-940, 2012.10(in Japanese) 山田哲, 松本由香, 伊山潤, 五十子幸樹, 吉敷祥一, 池永昌容, 島田侑子, 小山毅，見波進，浅田勇人：東北地方太平洋沖地震等で被琰した鉄骨造文 教施設の調査-調查の概要- . 日本建築学会技術報告集 第 18 巻 第 40 号, pp.935-940, 2012.10
3)Hara, S. , Tamai, H. , Takamatsu, T. , Haitani, T. , Hattori, A. and Kobata, H. : Life Prolongiation of Steel buildings Using Carbon Fiber Reinforced Plate Part1, Summaries of Technical Papers of Annual Meeting, Architectural Institute of Japan, C-1 structure III, pp.601-608, 2005.7

原伸幸, 玉井宏章, 高松隆夫, 灰谷徳治, 服部明生, 小畑寛行：炭素繊維プ レートによる鋼構造建物の長寿命化に関する研究その 1 . 日本建築学会大 会学術講演梗概集, C-1 構造, pp.601-602, 2005.7

4)Akiyama, S. , Asano, T. , Sasaki, S. , Sasaki, Y. and Katsura, D.: Seismic Retrofit Method for Steel Members with Steel Plate and Self-drilling Tapping Screws Part1, Summaries of Technical Papers of Annual Meeting, Architectural Institute of Japan, C-1 structure III, pp.929-930, 2007.7

秋山茂雄,浅野孝,佐々木聡,佐々木康人,桂大輔: ドリルタッピングねじ接合 を用いた鋼構造部材の耐震補強工法に関する研究その 1 . 日本建築学会大 会学術講演梗概集,C-1 構造,pp.929-930, 2007.7

5)Soda, S. , Hanai, T. , Minagawa, T. , Miyazu,Y. and Maruno, S.: Development of DIY Seismic Retrofit of Low-rise Steel Structures Part1, Summaries of Technical Papers of Annual Meeting, Architectural Institute of Japan, structure III, pp.1003-1004, 2012.7

曽田五月也，花井勉，皆川隆之，宮津裕次，丸野悟司：低層鉄骨造の損傷制 御用 DIY 制震補強に関する技術開発その 1 . 日本建築学会大会学術講演梗 概集，構造 III , pp.1003-1004，2012.7

6)Ueki, R. , Tomatsuri, H. and Hirai, K. : Experimental Study on the Seismic Retrofit of Steel Structures by Non Welding Joint Method, Summary of Technical Papers of Annual Meeting Architectural Institute of Japan, structure III, pp.723-724, 2013.8

植木理枝子，都祭弘幸，平井敬二：無溶接接合工法による鋼構造物の耐震 補強に関する実験研究。日本建築学会大会学術講演梗概集，構造 III， pp.723-724, 2013.8

7)Asada, H. , Yamada, S. , Kishiki, S. and Minowada, S. : Investigation of Tension Brace Connections in Existing Steel Gymnasium and Evaluation on Ultimate Strength of Fillet Welded Gusset Plate Connection, Journal of Structural and Construction Engineering (Transactions of AIJ), Vol.76,No659, pp.185-193, 2011.1(in Japanese) 浅田勇人, 山田哲, 吉敷祥一, 箕輪田翔: 既存屋内運動場における引張ブレ 一ス接合部の調査とそれに基づいたガセットプレート隅肉溶接部の破断耐 力評価. 日本建築学会構造系論文集 第 76 巻 第 659 号, pp.185-193, 2011.1

8) Kishiki, S. , Kajima, N. and Satsukawa, K.: Seismic Retrofit for Bolted Angle Connections using Additional Member on the Leg Plate , Journal of Structural and Construction Engineering (Transactions of AIJ), Vol.84,No757, pp.447-457, 2019.3(in Japanese) 吉敷祥一,梶間夏美,薩川恵一：山形鋼高力ボルト接合部の突出脚への並列 材付加による乾式補強. 日本建築学会構造系論文集 第 84 巻 第 757 号, pp.447-457, 2019.3

9)Maezawa , M. , Nishizaki , Y. , Ishida , T. and Yamada, S. : Experimental Study on Seismic Rehabilitation Method for Existing Braces with Knee Members, Summaries of Technical Papers of Annual Meeting, Architectural Institute of Japan ,structure III, pp.1315-1318, 2017.7

前澤将男, 西崎禎希, 石田孝徳, 山田哲：既存ブレースの方杖型補強法に 関する実験的研究. 日本建築学会大会学術講演梗概集, 構造 III, pp. 1315-1318, 2017.7

10)Architectural Institute of Japan: Recommendation for Design of Connections in Steel Structures, Maruzen,2012(inJapanese) 日本建築学会：鋼構造接合部設計指針, 丸善, 2012

11)Japan Building Disaster Prevention Association : 2011 revised edition Guidelines and the commentary of earthquake-resistant diagnosis and seismic renovation of Existing Steel Frame Buildings for Earthquake-resistant Repair Promotion Law, Japan Building Disaster Prevention Association, 2011(in Japanese) 日本建築防災協会: 2011 年改訂版 耐震改修促進法のための既存鉄骨造建 築物の耐震診断および而震改修指針・同解説，日本建築防㷋協会, 2011 


\title{
STUDY ON THE SEISMIC RETROFIT OF ANGLE BRACE JOINT \\ USING KNEE MEMBERS
}

\author{
Masao MAEZAWA ${ }^{* 1}$, Ryohei KUWADA ${ }^{* 1}$, Takanori ISHIDA*2, \\ Shoichi KISHIKI ${ }^{* 3}$, Keiichi SATSUKAWA ${ }^{* 4}$ and Satoshi YAMADA ${ }^{* 5}$ \\ ${ }^{* 1}$ Nippon Steel Corporation, M.Eng. \\ *2 Assist. Prof., FIRST, IIR, Tokyo Institute of Technology, Dr.Eng. \\ ${ }^{*} 3$ Assoc. Prof., FIRST, IIR, Tokyo Institute of Technology, Dr.Eng. \\ ${ }^{* 4}$ Prof., Dept. of Architecture, Aichi Institute of Technology, Dr.Eng. \\ ${ }^{*}$ Prof., FIRST, IIR, Tokyo Institute of Technology, Dr.Eng.
}

The brace joint fracture was observed in several severe earthquakes which occurred in the past. That's because fracture prevention of a brace joint wasn't considered by old seismic design code. The important problem to promote seismic retrofit works of a brace joint in the future is fire-less and compact seismic retrofit method which doesn't use a welding and gas-cutting.

In this paper, the seismic retrofit method with the knee members for preventing the joint fracture of the angle brace was proposed. This method joins a brace, a column and a girder using the knee members and high tension bolt. Therefore it became possible to build this method without using fire at a site of retrofit works. And an obstacle in retrofit works could be avoided by adjusting the location and holding angle of the knee members. This method aims at fracture prevention of a brace joint by adding a load transfer routes of the knee members.

A series of loading test and a series of analysis have been carried out to investigate strength improvement effect of this method. The strength and stiffness evaluation model of each part in this method were proposed. And a relation between story drift angle of the frame which occurred by the seismic force and the load sharing ratio of the knee members was investigated analytically.

As a result, the following knowledge was obtained.

[1] The joint fracture prevention before a brace yielding was confirmed by installing the knee members in both sides of the brace. However, story drift angle of the frame which occurred by the seismic force wasn't considered by this result.

[2] The load sharing ratio could be expressed by an evaluation model proposed by this paper. However, story drift angle of the frame which occurred by the seismic force wasn't considered by this result.

[3] Consideration is needed by the load sharing ratio changed by holding angle of the knee members, the installed height of the knee members, stiffness of the knee members and holding angle of a brace to make this method reach the reinforcement target. And it's necessary to consider story drift angle of the frame which occurred by the seismic force. 